Georgia State University

ScholarWorks @ Georgia State University

Political Science Faculty Publications

Department of Political Science

Winter 2006

\title{
Success Matters: Casualty Sensitivity and the War in Iraq"
}

Jason Reifler

Georgia State University, jreifler@gsu.edu

Christopher Gelpi

Peter Feaver

Follow this and additional works at: https://scholarworks.gsu.edu/political_science_facpub

Part of the Political Science Commons

\section{Recommended Citation}

Reifler, Jason; Gelpi, Christopher; and Feaver, Peter, "Success Matters: Casualty Sensitivity and the War in Iraq"'" (2006). Political Science Faculty Publications. 10.

https://scholarworks.gsu.edu/political_science_facpub/10

This Article is brought to you for free and open access by the Department of Political Science at ScholarWorks @ Georgia State University. It has been accepted for inclusion in Political Science Faculty Publications by an authorized administrator of ScholarWorks @ Georgia State University. For more information, please contact scholarworks@gsu.edu. 
Success Matters

\author{
Casualty Sensitivity and the War in Iraq
}

Christopher Gelpi, Peter D. Feaver, and Jason Reifler

Since the Vietnam War,

policymakers have worried that the U.S. public will support military operations only if the human costs of the war, as measured in combat casualties, are minimal. ${ }^{1}$ A combination of circumstances makes the public response to the ongoing war in Iraq during the presidential campaign of 2003-04 an important opportunity to evaluate this hypothesis. First, the war in Iraq is both the most controversial and most deadly U.S. military operation since the Vietnam War. By Election Day in November 2004, nearly 1,200 U.S. soldiers had been killed in action. At the same time, Americans seemed increasingly divided over President George W. Bush's reasons for going to war; both the Kay report and the 9/11 commission report raised questions about the strength of the ties between Saddam Hussein, weapons of mass destruction (WMD), and the al-Qaida terrorist network. ${ }^{2}$ Moreover, the public was deluged with information about the

Christopher Gelpi is Associate Professor of Political Science at Duke University. Peter D. Feaver, Alexander F. Hehmeyer Professor of Political Science and Public Policy at Duke University, is on leave and serving as Special Adviser for Strategic Planning and Institutional Reform on the National Security Council staff. This article reflects his personal views from work he did before joining the government and does not represent the official position of the U.S. government or the George W. Bush administration. Jason Reifler is Assistant Professor of Political Science at Loyola University Chicago.

The authors would like to thank the participants in the Wielding American Power: Managing Interventions after September 11 project at the Triangle Institute for Security Studies and the Terry Sanford Institute for Public Policy at Duke University for their helpful comments in shaping this work. Moreover, they would like to thank John Aldrich, Bear Braumoller, John Brehm, Claudia Deane, Alexander Downes, Joseph Grieco, Bruce Jentleson, Robert Keohane, Steven Kull, Eric Larson, Charles Lipson, John Mueller, Janet Newcity, Emerson Niou, Robert Pape, and two anonymous reviewers for their helpful comments on the manuscript or the survey instruments. This research was supported by grants from the Carnegie Corporation and the National Science Foundation.

1. Unless otherwise noted, we use the term "casualties" to refer to "deaths." We recognize that in military parlance, casualties means dead and wounded, a much higher number in any conflict. In popular usage, however, the word "casualties" has generally meant those who died while performing their mission. In our own polling, except where noted, we used "deaths" in all relevant question wordings so our claims are not contaminated by any public confusion about the terms. In this article we look only at one aspect of the cost equation-"U.S. military deaths in combat," or "our casualties."

2. The Kay report is not officially published in any single document. David Kay submitted an interim report from the Iraq Survey Group (ISG) to the House Permanent Select Committee on Intelligence, the House Committee on Appropriations, Subcommittee on Defense, and the Senate Select Committee on Intelligence, on October 2, 2003, but he resigned prior to submitting a final report. His most influential public statement on the ISG's findings was his testimony to the Senate Armed Services Committee on January 28, 2004, following his decision to resign from the ISG. For a transcript of Kay's October 2, 2003, testimony, see http://cia.gov/cia/public_affairs/speeches/ 
war and its cost in American lives. Combat in Iraq was the most covered story on the major network television news broadcasts in 2004 with nearly twice as many minutes of airtime as the second most covered story: postwar reconstruction of Iraq. ${ }^{3}$

In this article, we argue that the public will tolerate significant numbers of U.S. combat casualties under certain circumstances. To be sure, the public is not indifferent to the human costs of American foreign policy, but casualties have not by themselves driven public attitudes toward the Iraq war, and mounting casualties have not always produced a reduction in public support. The Iraq case suggests that under the right conditions, the public will continue to support military operations even when they come with a relatively high human cost.

Our core argument is that the U.S. public's tolerance for the human costs of war is primarily shaped by the intersection of two crucial attitudes: beliefs about the rightness or wrongness of the war, and beliefs about a war's likely success. The impact of each attitude depends upon the other. Ultimately, however, we find that beliefs about the likelihood of success matter most in determining the public's willingness to tolerate U.S. military deaths in combat.

Our findings imply that the U.S. public makes reasoned and reasonable judgments about an issue as emotionally charged and politically polarizing as fighting a war. Indeed, the public forms its attitudes regarding support for the war in Iraq in exactly the way one should hope they would: weighing the costs and benefits. U.S. military casualties stand as a cost of war, but they are a cost that the public is willing to pay if it thinks the initial decision to launch the war was correct, and if it thinks that the United States will prevail.

We explore the public's tolerance for casualties through a close examination of polling data from the beginning of the Iraq war through the 2004 U.S. election-that is, for the first twenty months of the war. Of course, the Iraq war has continued since, and by the winter of 2005, U.S. public opinion on the war had shifted somewhat. Consider just one, oft-quoted statistic: in April 2003 at the height of "major combat operations," 76 percent of the public approved of

2003/david_kay_10022003.html. For a transcript of Kay's January 28, 2004, testimony, see http:// www.ceip.org/files/projects/npp/pdf/Iraq/kaytestimony.pdf. For a complete review of the controversy over Iraqi WMD programs leading up to the Iraq war, see http://www.gwu.edu/ $\sim$ nsarchiv/index.html. See The 9/11 Commission Report: Final Report of the National Commission on Terrorist Attacks upon the United States (New York: W.W. Norton, 2004).

3. For the Tyndall Report summary of 2004 campaign coverage, see http://www.tyndallreport .com. 
President Bush's handling of the war; by the time of the U.S. election in November 2004, that number had dropped to 47 percent; a year later, it had dropped below 35 percent. $^{4}$

This movement in public opinion in a conflict that remains ongoing as this article goes to press might lead some to discount an argument tested primarily on data from the first twenty months of the war. Dismissing our findings in this way is unwarranted for at least two reasons. First, this article is advancing a model of the structure of public opinion, not simply describing the relatively high level of public support that existed in certain stages of the war. Our model can be assessed based on twenty months of data and then, if supported, applied to new data as they come available. We believe that the noticeable decline in public support in 2005 fits our model rather well. In our view, public support has not eroded in 2005 because of mounting casualties per se. After all, the United States suffered about the same number of casualties between March and July 2005-a period of marked decline in support-as it did during the months from June through October 2004-when support was on the rise. Support hit a peak, moreover, in January 2005 despite large numbers of U.S. casualties in November and December 2004. Instead, we believe that the decline in public support for the war reflects the mounting death toll combined with a perceived lack of measurable progress toward "success" that eroded the public's hopes that the war may eventually be won. Public support for the war in January 2005 clearly reflected public optimism in the wake of the strikingly successful Iraqi election that month. Since that time, however, we would argue that political deadlock over the drafting of a constitution, a lack of demonstrable progress regarding the efficacy of Iraqi security forces, and the persistence of deadly attacks by insurgents undermined that optimism. Of course, the results of the October 15, 2005, referendum on the Iraqi constitution and the subsequent national election will also need to be factored into the mix. Our model claims that public estimations of the success of those milestones-and the ability of insurgents to react-will further shape public tolerance for the war.

Second, truncating the time-series to stop in November 2004 does not bias our results in favor of our model. Our time-series data are long enough to cover factors that might be considered competing arguments: the shock of escalating casualties to a level ten times the number suffered during the period of major combat operations; the shock of the failure to find large stockpiles of

4. The 2003 and 2004 data are from a national sample of adults as sampled by Gallup; 2005 data are from a comparable survey by CBS News. As reported on http://www.pollingreport.com. 
WMD; and the shock of a bitter partisan debate over the Iraq war in the context of a close-fought presidential election. These are precisely the elements pundits cite for explaining the erosion of U.S. public support for the war in 2005. Often these same pundits were claiming that these very factors would cause a collapse of public support in 2004. Of course, our argument should be continuously tested against new data and, indeed, our findings raise many new questions that warrant further study. But we have ample data to reach a conclusion that is likely to withstand the test of time.

Our argument proceeds in four stages. First, we clarify our understanding of casualty sensitivity and place our work in the context of the extensive research on this topic. Second, through an analysis of weekly presidential approval ratings from January 2003 until November 2004, we find that the public's willingness to tolerate casualties and continue to support the president varies substantially depending upon the context in which the casualties occur. Third, we examine the factors that shape the public's tolerance for casualties through an analysis of individual-level attitudes toward casualties and the war in Iraq. Fourth, because our argument identifies "expectations of success" as the key factor in shaping public casualty sensitivity, we explore how the public defines success in Iraq and what indicators the public trusts for measuring whether success is likely or not.

\section{Conceptions of Casualty Sensitivity}

Casualty sensitivity differs from casualty phobia, a reflexive opposition to any casualties. Following Peter Feaver and Christopher Gelpi, casualty sensitivity recognizes the human toll as a cost of war. ${ }^{5}$ The public would always like to assume less of this cost, but a nonzero human cost does not mean that it will oppose war. Casualty sensitivity is, to put it crudely, one's price sensitivity to the human cost of war. As with other forms of price sensitivity, some members of the public are more sensitive to the costs than others. We see in the public a continuum of casualty sensitivity ranging from the minimally sensitive- those who view casualties as a necessary cost of war and not a determining factor in shaping support-to the maximally sensitive-those who support only military missions that guarantee virtually no casualties.

Casualty phobia represents one end of this continuum, and in these terms,

5. Peter D. Feaver and Christopher Gelpi, Choosing Your Battles: American Civil-Military Relations and the Use of Force (Princeton, N.J.: Princeton University Press, 2004). 
the conventional wisdom since the Vietnam War has been that the U.S. public is best thought of as casualty phobic. Analysts of U.S. public opinion, however, have not generally endorsed this conventional view. The scholarly consensus has evolved over time and can perhaps best be understood as three interlocking (but not necessarily successive) debates.

The first debate concerns whether the number of casualties affects public support for war according to a fixed pattern of inexorable decline or whether the public views casualties and the use of force through a cost-benefit calculus. Early research during the Vietnam War emphasized what came to be called the "rally 'round the flag" effect. Viewed this way, public casualty sensitivity was not a debilitating constraint on U.S. military power. ${ }^{6}$

In a pioneering analysis of public opinion regarding Vietnam, Jeffrey Milstein and William Mitchell found that public support dropped as the U.S. military commitment expanded and as casualties increased, whereas public support climbed when the burden was shifted to the shoulders of the Vietnamese themselves. ${ }^{7}$ John Mueller built on this work with a landmark study of public opinion on the Vietnam War (with a comparison to the Korean War). ${ }^{8}$ Mueller is famous for arguing that public support for the Vietnam War dropped in proportion to the log of casualties. ${ }^{9}$ Viewed in toto, Mueller's finding does not support the casualty-phobia thesis. However, Mueller was arguing that public support dropped reflexively, and more to the point, inexorably. His oft-quoted study thus fixed in the public mind the idea that support for Vietnam buckled as the body bag toll mounted, and this gradually hardened into the conventional wisdom that the public is reflexively casualty phobic.

6. See Sidney Verba, Richard A. Brody, Edwin B. Parker, Norman H. Nie, Nelson W. Polsby, Paul Ekman, and Gordon S. Black, "Public Opinion and the War in Vietnam," American Political Science Review, Vol. 61, No. 1 (June 1967), pp. 317-333; and Kenneth N. Waltz, Foreign Policy and Democratic Politics: The American and British Experience (Boston: Little, Brown, 1967).

7. Jeffrey S. Milstein and William C. Mitchell, “Dynamics of the Vietnam Conflict: A Quantitative Analysis and Computer Simulation," Peace Research Society (International) Papers, No. 10 (1968); Jeffrey S. Milstein, "Changes in Domestic Support and Alternative Military Actions in the Vietnam War, 1965-1968," paper delivered at the Twenty-third Annual Meeting of the Western Political Science Association, April 3, 1969; Jeffrey S. Milstein, "The Vietnam War from the 1968 Tet Offensive to the 1970 Cambodian Invasion," in H.R. Alker, K.W. Deutsch, and A.H. Stoetzel, Mathematical Approaches to Politics (New York: Elsevier, 1973); and Jeffrey S. Milstein, Dynamics of the Vietnam War: A Quantitative Analysis and Predictive Computer Simulation (Columbus: Ohio State University Press, 1974).

8. For the central thesis, see John Mueller, "Trends in Popular Support for the Wars in Korea and Vietnam," American Political Science Review, Vol. 65, No. 2 (June 1971), pp. 358-375. For the full compilation of polls, see John Mueller, War, Presidents, and Public Opinion (New York: Wiley and Sons, 1973).

9. Mueller, War, Presidents, and Public Opinion, p. 62. 
Mueller later reinforced the "inexorable decline" view with his analysis of public opinion during the 1991 Persian Gulf War, which emphasized that public support was far more precarious than the euphoria over the quick victory might indicate. ${ }^{10}$ Other research also showed a direct link between mounting casualties, antiwar protests, and subsequent changes in U.S. governmental policy. $^{11}$

This view of a fixed pattern of declining public support with rising casualties was challenged in a series of major scholarly investigations assessing public opinion and national security during the Cold War. These studies painted a picture of a "rational public," one capable of responding to elite debates and weighing the complexities of foreign policy. ${ }^{12}$ The public, in this way, went through what Alvin Richman called a simple "ends-means" calculus. ${ }^{13}$ Applying this approach, Eric Larson found, contrary to Mueller, that a complex cost-benefit calculation fits the data better than a reflexive, logarithmic response. ${ }^{14}$ Today, the scholarly consensus is nearly unanimous in favor of the "rational cost-benefit" model, and Larson's oft-cited version serves as a point of departure for much subsequent research in the field.

The cost-benefit model, however, is not by itself a rebuttal of the casualty-

10. John Mueller, Policy and Opinion in the Gulf War (Chicago: University of Chicago Press, 1994). Scott Gartner and Gary Segura revised this argument somewhat, noting that support for the Korean and Vietnam Wars declined with logged casualties during periods when the casualty rates were low; but in periods of high casualty rates, public support dropped with marginal casualties, not logged cumulative casualties. See Gartner and Segura, "War Casualties and Public Opinion," Journal of Conflict Resolution, Vol. 42, No. 3 (September 1998), pp. 278-320.

11. Mark Lorell and Charles Kelley, Casualties, Public Opinion, and Presidential Policy during the Vietnam War, R-3060-AF (Santa Monica, Calif.: RAND, 1985).

12. Ole Holsti and James Rosenau, American Leadership in World Affairs: Vietnam and the Breakdown of Consensus (Boston: Allen and Unwin, 1984); Bruce Russett, Controlling the Sword: The Democratic Governance of National Security (Cambridge, Mass.: Harvard University Press, 1990); Eugene Wittkopf, Faces of Internationalism: Public Opinion and American Foreign Policy (Durham, N.C.: Duke University Press, 1990); Ronald Hinckley, People, Polls, and Policy Makers (New York: Lexington, 1992); Benjamin Page and Robert Shapiro, The Rational Public: Fifty Years of Trends in Americans' Policy Preferences (Chicago: University of Chicago Press, 1992); Paul Sniderman, "The New Look in Public Opinion Research," in Ada Finifter, ed., The State of the Discipline II (Washington, D.C.: American Political Science Association, 1993); John Zaller, The Nature and Origins of Public Opinion (New York: Cambridge University Press, 1994); Alvin Richman, "When Should We Be Prepared to Fight?" Public Perspective, Vol. 6, No. 3 (April/May 1995), p. 44; and Ole Holsti, Public Opinion and American Foreign Policy (Ann Arbor: University of Michigan Press, 1996). For a more skeptical view, but not one that dismisses polling altogether, see Scott Althaus, Collective Preferences in Democratic Politics: Opinion Surveys and the Will of the People (Cambridge: Cambridge University Press, 2003).

13. Richman, "When Should We Be Prepared to Fight?"

14. Eric Larson, Casualties and Consensus: The Historical Role of Casualties in Domestic Support for U.S. Military Operations (Santa Monica, Calif.: RAND, 1996). 
phobia thesis, and, indeed, the model has given rise to the second debate in the academic literature: If the public applies something like an economic rational calculation about war, how inelastic is the public's "demand" for war? ${ }^{15}$ Thus, in more recent work, Mueller explicitly accepts the cost-benefit model, but, writing before the terrorist attacks of September 11, 2001, he argued that the public saw so little benefit in most military missions that in effect the costbenefit calculation was functionally equivalent to a casualty-phobic posture. ${ }^{16}$ Likewise, Louis Klarevas endorses the cost-benefit model, but then elsewhere argues that for some key categories of missions, the public's sensitivity to casualties is so high that trivial numbers of casualties can produce a "Somalia syndrome."17 Most scholars who have examined public opinion polls closely come down on the other side, however, concluding that the demand, although not completely inelastic, is nevertheless not as price sensitive as to approximate casualty phobia. ${ }^{18}$

15. In fact, the positions of the various participants in this first wave of debate are not as sharply distinct as the literature implies. For example, John Mueller's findings about the erosion of support for the Korean and Vietnam Wars could be consistent with a cost-benefit calculation by members of the public. Viewed in this way, the mounting casualty tolls in those wars meant that the costs for securing the goals at stake were rising. If the value of the goals remains constant, then one would expect rising costs to turn the net cost-benefit calculation against supporting the mission.

16. Karl P. Mueller, "Politics, Death, and Morality in U.S. Foreign Policy," Aerospace Power Journal, Vol. 14, No. 2 (Summer 2000), pp. 12-16.

17. This term derives from the precipitous drop in public support for the U.S. intervention in Somalia after the killing of U.S. Rangers there in 1993. For slightly differing views of the "Somalia syndrome," compare Louis Klarevas, "The 'Essential Domino' of Military Operations: American Public Opinion and the Use of Force," International Studies Perspectives, Vol. 3, No. 4 (November 2002), pp. 417-437, with Louis Klarevas, "Trends: The United States Peace Operation in Somalia," Public Opinion Quarterly, Vol. 64, No. 4 (Winter 2000), pp. 523-540.

18. This is the conclusion of the following poll-based analyses: Bruce Jentleson, "The Pretty Prudent Public: Post-Vietnam American Opinion on the Use of Military Force," International Studies Quarterly, Vol. 36, No. 1 (March 1992), pp. 49-74; Richman, "When Should We Be Prepared to Fight?"; Steven Kull, "What the Public Knows That Washington Doesn't," Foreign Policy, No. 102 (Winter 1995/96), pp. 102-116; Larson, Casualties and Consensus; Warren Strobel, Late-Breaking Foreign Policy: The News Media's Influence on Peace Operations (Washington, D.C.: United States Institute of Peace, 1997); Rebecca L. Britton and Bruce Jentleson, "Still Pretty Prudent," Journal of Conflict Resolution, Vol. 42, No. 4 (August 1998), pp. 395-418; James Burk, "Public Support for Peacekeeping in Lebanon and Somalia: Assessing the Casualties Hypothesis," Political Science Quarterly, Vol. 114, No. 1 (Spring 1999), pp. 53-78; Steven Kull and I.M. Destler, Misreading the Public: The Myth of a New Isolationism (Washington, D.C.: Brookings, 1999); Peter Feaver and Christopher Gelpi, "How Many Deaths Are Acceptable? A Surprising Answer," Washington Post, November 7, 1999; Philip Everts, "When the Going Gets Rough: Does the Public Support the Use of Force?" World Affairs, Vol. 162, No. 3 (Winter 2000), pp. 91-107; Philip Everts, "War without Bloodshed? Public Opinion and the Conflict over Kosovo," in Everts and Pierangelo Isernia, eds., Public Opinion and the International Use of Force (New York: Routledge, 2001); Andrew Erdmann, “The U.S. Presumption of Quick, Costless Wars," Orbis, Vol. 43, No. 3 (Summer 1999), pp. 363-382; Philip Everts, Democracy and Military Force (New York: Palgrave, 2002); Feaver and Gelpi, Choosing 
The third debate takes the issue of elasticity a step further: What factors shape the elasticity of demand for military missions? Put another way, under what conditions will the number of casualties cause public support for a given mission to decline more rapidly or more slowly? There is a wide scholarly consensus that multiple factors may be at work at the same time. ${ }^{19}$ What distinguishes different scholars in this third wave of debate, however, is the pride of place they give to certain factors. ${ }^{20}$

First, Bruce Jentleson argues that the "pretty prudent" public bases its casualty tolerance on "the principal policy objective (PPO)" envisioned by the military operation. ${ }^{21} \mathrm{He}$ contends that the public will accept missions with PPOs focused on what he calls "foreign policy restraint" (FPR) goals as important missions that are worth a substantial cost. Foreign policy restraint missions include the traditional military tasks of using force to coerce an adversary en-

Your Battles; and Richard C. Eichenberg, "Victory Has Many Friends: U.S. Public Opinion and the Use of Military Force, 1981-2005," International Security, Vol. 30, No. 1 (Summer 2005), pp. 140-177. 19. Eric Larson, "Putting Theory to Work: Diagnosing Public Opinion on the U.S. Intervention in Bosnia," in Miroslav Nincic and Joseph Lepgold, eds., Being Useful: Policy Relevance and International Relations Theory (Ann Arbor: University of Michigan Press, 2000), pp. 174-236; and Klarevas, "The 'Essential Domino' of Military Operations."

20. Here we list only the factors that might vary from case to case in the current era. A number of other arguments emphasize different factors that would explain changes in the underlying casualty tolerance from what it might have been in previous generations. Thus, Edward Luttwak argues that the U.S. public is more casualty sensitive now than in the time of World Wars I and II because of the lower birth rate. See Edward Luttwak, "Towards Post-heroic Warfare," Foreign Affairs, Vol. 74, No. 3 (May-June 1995), pp. 109-122; and Edward Luttwak, "A Post-heroic Military Policy," Foreign Affairs, Vol. 75, No. 4 (July-August 1996), pp. 33-44. Charles Moskos argues that the public is more casualty sensitive now because they see that children of the elite are not at risk in most military missions. See Moskos, "Grave Decision: When Americans Accept Casualties," Chicago Tribune, December 12, 1995. Harvey Sapolsky and Jeremy Shapiro argue that casualty phobia has driven changes in technology, which have, in turn, reinforced casualty phobia by fostering unrealistic expectations of the likely low human toll of war. See Sapolsky and Shapiro, "Casualties, Technology, and America's Future Wars," Parameters, Vol. 26, No. 2 (Summer 1996), pp. 119-127. Numerous observers have argued that the advent of near-real-time television coverage of military operations has heightened public casualty sensitivity by giving the deaths a vividness and immediacy that make them more shocking. See, for example, Frank Stech, "Winning CNN Wars," $P a$ rameters, Vol. 14, No. 3 (Fall 1994), pp. 37-56; Johanna Neuman, Lights, Camera, War: Is Media Technology Driving International Politics? (New York: St. Martin's, 1996); and Steven Livingston, "Clarifying the CNN Effect: An Examination of Media Effects According to Type of Military Intervention," research paper R-18 (Cambridge, Mass.: Joan Shorenstein Center on Press, Politics, and Public Policy, John F. Kennedy School of Government, Harvard University, 1997). Logically, these works belong in the first or second wave because they claim that the public is, in fact, highly casualty sensitive and blame a factor that is largely unavoidable and so should apply with equal force to every military mission the United States might consider. These issues are explored in greater detail in Christopher Gelpi, Peter Feaver, and Jason Reifler, "Paying the Human Costs of War," Duke University, 2005.

21. Jentleson "The Pretty Prudent Public"; and Jentleson and Britton "Still Pretty Prudent." 
gaged in aggressive action against the United States or its allies. On the other hand, Jentleson argues that "humanitarian intervention" missions will enjoy public support only if the costs are relatively low. Finally, he expects that missions focused on "internal political change" will contend with even more fragile levels of public support.

Second, Eric Larson argues that public casualty tolerance follows domestic elite casualty tolerance. ${ }^{22}$ When domestic elites line up in a consensus behind the mission, public support will be robust even in the face of mounting costs, but when domestic elites are divided, even a small number of casualties will quickly diminish public support.

Third, Steven Kull argues that public support for a military mission will be more robust if the public sees that other countries likewise support the mission, and thus the United States is not obliged to bear all of the costs. ${ }^{23}$ Multilateral support may function as an elite cue-"'this mission must be worth the cost because lots of other states are supporting it" ${ }^{24}$ —or the public may simply prefer to have the burden distributed more evenly.

Finally, Feaver and Gelpi identify expectations of success as the crucial factor in explaining the public's tolerance of casualties. ${ }^{25}$ When the public be-

22. Larson, Casualties and Consensus, applies John Zaller's model of how elites cue public opinion. See Zaller, The Nature and Origins of Public Opinion. Larson, "Putting Theory to Work," offers a model for weighing multiple factors simultaneously, including various indices that attempt to measure the public's perceived utility in a given military mission, expectations of success, and leadership cuing. He gives pride of place, however, to leadership cuing.

23. Steven Kull, I.M. Destler, and Clay Ramsay, The Foreign Policy Gap: How Policymakers Misread the Public (Washington, D.C.: Center for Strategic and International Studies, 1997); Kull and Destler Misreading the Public; Steven Kull and Clay Ramsay, "A Rejoinder from Kull and Ramsay," International Studies Perspectives, Vol. 1, No. 2 (August 2000), pp. 202-205; and Steven Kull, Clay Ramsay, Stefan Subias, Phillip Warf, and Monica Wolford, "Americans on the Conflict with Iraq," PIPA/ Knowledge Networks poll, October 2, 2002.

24. Joseph Grieco hypothesizes this as the critical factor behind a public preference for multilateralism in Grieco, "Let's Get a Second Opinion: Allies, the U.N., and U.S. Public Support for War," Duke University, 2003.

25. Feaver and Gelpi, "How Many Deaths Are Acceptable?"; Feaver and Gelpi, Choosing Your Battles; and Peter Feaver, "To Maintain That Support, Show Us What Success Means," Washington Post, October 7, 2001. Kull and Ramsay reach a similar conclusion: "Americans do not and are not likely to respond reflexively to losses by wanting to withdraw from a military operation ... provided that the public has support for the operation in the first place and believes that it is likely to succeed." See Steven Kull and Clay Ramsay, "The Myth of the Reactive Public: American Attitudes on Military Fatalities in the Post-Cold War Period," in Everts and Isernia, Public Opinion and the International Use of Force, pp. 205-228. In their analysis of Dutch public opinion surrounding the Bosnian operation, Jan van der Meulen and Marijke de Konink concluded that expectations of success were the best predictor of Dutch casualty tolerance. See van der Meulen and de Konink, "Risky Missions: Dutch Public Opinion on Peacekeeping in the Balkans," in Everts and Isernia, Public Opinion and the International Use of Force, pp. 116-138. See also Steven Kull "Review of Eric 
lieves that the mission will succeed, it continues to support the mission, even as costs mount. When the public thinks victory is unlikely, even small costs will cause support to plummet. Note that the critical belief specified here is the expectation of eventual future success, not necessarily assessments of how the war is going right now or most recently. ${ }^{26}$ In a comprehensive analysis of aggregate public opinion trends from 1981 through 2004, Richard Eichenberg reached a similar conclusion: "Successful military operations enjoy high support even when the objective is unpopular and casualties are suffered."27

Each of these studies establishes convincingly that the favored factor matters (and most also show that other factors matter, too). But little progress has been made in assessing the relative importance of these factors. In the sections that follow, we evaluate these and other arguments through a reanalysis of publicly available polls and a detailed analysis of a series of proprietary polls we designed explicitly to tap into public attitudes on casualties. ${ }^{28}$ This method allows us to combine various forms of data suited for different types of inferences. First, to assess the first two waves of the casualty tolerance debate regarding the inexorable decline of support in response to casualties, we examine the aggregate level of presidential approval and how it responds to U.S. military deaths in Iraq from January 2003 through the presidential election in November 2004. Next, to assess the third wave of debate on the sources of variation in casualty tolerance, we analyze individual-level data on tolerance for casualties in Iraq. This represents important progress in the study of

Larson's Casualties and Consensus," Public Opinion Quarterly, Vol. 61, No. 4 (Winter 1997), pp. 672674 .

26. In this way, the category "expectations of success" differs from the variable highlighted by Gartner and Segura-marginal casualty rates. In their words, "Recent casualties send a signal that the war is not going well-a signal that dominates other cost measures when the marginal casualty level is increasing." Gartner and Segura, "War Casualties and Public Opinion," p. 295.

27. Eichenberg, "Victory Has Many Friends," p. 147.

28. The proprietary polls include a telephone survey of a random digit dial (RDD) national sample of 1,203 adults conducted by the Parker Group from September 22 to October 12, 2003, and seven additional surveys of national representative samples (using a different and shorter instrument) administered via the internet by Knowledge Networks: Wave 1 (February 6-20, 2004, 891 respondents), Wave 2 (February 25-March 4, 870 respondents), Wave 3 (March 5-18, 930 respondents), Wave 4 (March 19-April 2, 889 respondents), Wave 5 (April 2-16, 881 respondents), Wave 6 (April 17-29, 899 respondents), and Wave 7 (June 18-28, 900 respondents). Finally, we conducted a more extensive survey through Knowledge Networks in the weeks leading up to the 2004 presidential election: Wave 8 (October 15-November 1, 1,125 respondents). The Knowledge Networks data are equivalent to the national RDD sample because they draw samples from a large panel of respondents that is a national probability sample. For more information on the Knowledge Networks methodology, see http://www.knowledgenetworks.com. The full survey instruments are available from the authors. 
casualty tolerance because so much of the previous work in this area has been hampered by an exclusive reliance on aggregate data.

\section{Aggregate Presidential Approval: U.S. Casualties and the War in Iraq}

We collected weekly data on U.S. combat deaths from January 1, 2003, through November 1, 2004. ${ }^{29}$ For the same period, we collected opinion data on three crucial issues: approval of the president in general, approval of the president's handling of the situation in Iraq, and whether the Iraq war has been "worth it." ${ }^{30}$ Presidential approval is asked frequently with standardized language, yielding a consistent measure of this attitude. The Iraq approval and "worth it" questions are asked less frequently, and their wording varies. For space reasons, we present only our analyses using presidential approval as the dependent variable. Attitudes toward these issues are strongly correlated with overall approval, and so the results do not change when using the other dependent variables. $^{31}$

Figure 1 displays average weekly approval ratings for President Bush from March 2003-immediately prior to the outbreak of war-until November 2004. The data indicate a substantial increase in approval that President Bush received after launching the war in Iraq. This bounce is consistent with the extensive literature on the "rally 'round the flag" effect. ${ }^{32}$ We divide our aggregation of the number of U.S. military deaths in Iraq into three time periods. The squares show U.S. fatalities during the "major combat" phase of the war, which covers the initial invasion of Iraq, the toppling of the Baath regime, and the movement of coalition forces into a position of occupation in Iraq. The cir-

29. The data were drawn from the following official military news sources: the Army Times, Navy Times, Air Force Times, and Marine Times. All are available at http://www.militarycity.com/valor/ honor.html.

30. For these data, see http://www.pollingreport.com. We included only polls with identical wording of the presidential approval question: "Do you approve or disapprove of the way George W. Bush is handling his job as president?" Thus polls such as the Zogby poll that introduce the category of "mixed feelings" toward the president were not included in our measure of presidential approval. For weeks in which there were multiple national polls, we took the average of these presidential approval ratings. We interpolated the one missing data point to obtain a continuous ninety-seven-observation, weekly time-series.

31. The correlation between overall presidential approval and approval of the president's handling of Iraq was 0.95 . The correlation of both of those variables with aggregate opinion of whether the war in Iraq has been "worth it" is 0.90 .

32. Bruce Russett, Controlling the Sword: The Democratic Governance of National Security (Cambridge, Mass.: Harvard University Press, 1990). 
Figure 1. Presidential Approval and Casualties from the War in Iraq

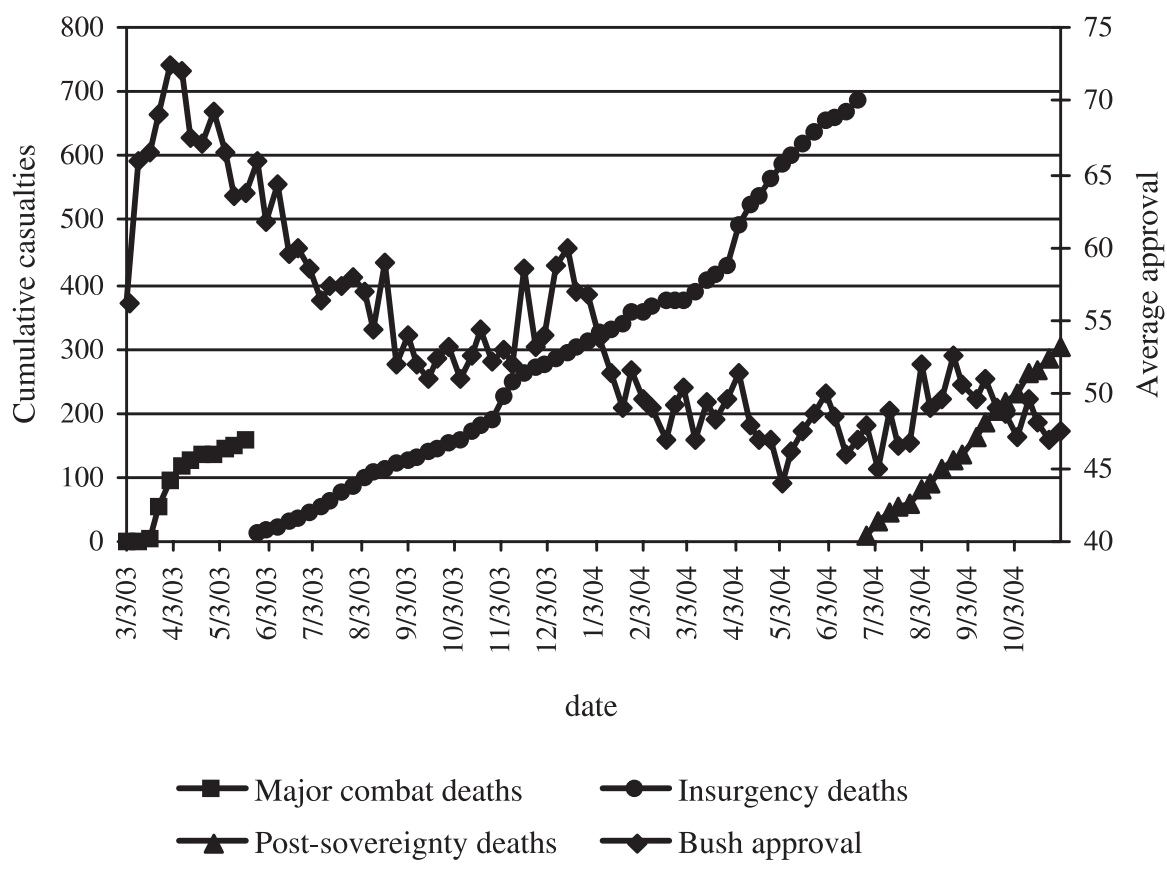

cles represent military deaths that occurred after the media began to report a coordinated resistance against the U.S.-led occupation in May 2003, but before the coalition transferred sovereignty to an Iraqi authority in June 2004. We refer to this as the "occupation" period. Finally, the triangles represent U.S. military deaths that occurred between the transfer of sovereignty to an Iraqi authority and the presidential election. We refer to this as the "sovereign Iraq" period of the war. ${ }^{33}$

Figure 1 indicates that U.S. military deaths did not appear to have the same impact on presidential approval in the "major combat," "occupation," and "sovereign Iraq" phases of the war. For example, presidential approval actu-

33. Media reports for this coding were drawn from the Tyndall Report, which records the amount of time that network news broadcasts spend on various issues each week. Based on the Tyndall Report, we identified the "occupation" period as beginning in late May 2003. The "Iraq sovereign period" began with the transfer of sovereignty in June 2004. For these data, see http://www .tyndallreport.com. 
ally increased despite the toll of U.S. casualties during the major combat phase of the war. This is not to say that the public increased its approval of the president because U.S. soldiers were being killed. Rather, the public rallied to support the president despite the casualties because it was confident that the United States would succeed. After the onset of the insurgency, however, presidential approval dropped steadily as the death toll increased. After the U.S. transfer of sovereignty to Iraq, on the other hand, U.S. casualties continued to mount at the same rate as during the occupation, but presidential approval oscillated at about 50 percent despite the mounting death toll.

Thus, at first glance, the data in Figure 1 seem to call into question the notion that casualties have a consistent or inexorable effect on presidential approval. Even if one dismisses the shift from major combat to occupation as the fading of a "rally 'round the flag," the second shift after the transfer of sovereignty remains a puzzle. Table 1 provides a more systematic analysis of the relationship between U.S. military deaths in Iraq and presidential approval. In addition to the number of deaths, we accounted for the impact of growth in the Dow Jones Industrial Average (DJIA), ${ }^{34}$ and we also included measures of the volume of media coverage, as measured by the content of the weeknight broadcasts of ABC, CBS, and NBC News. ${ }^{35}$ We divided media coverage into four periods: prewar, major combat, occupation, and sovereign Iraq. The prewar media coverage variable counts the number of minutes that the crisis with Iraq was covered; during the major combat, occupation, and sovereign Iraq phases of the war, we recorded the number of minutes per week that the network news broadcasts covered combat between the U.S. military and Iraqi or insurgent

34. Because our dependent variable is overall presidential approval, we control for the public perceptions of the overall performance of the U.S. economy. The Dow Jones Industrial Average (DJIA) represents an excellent summary measure of public perceptions of the economy for two central reasons. First, fluctuations in prices across a broad index such as the DJIA reflect changes across a number of economic indicators; traders incorporate a wide range of information about economic performance into the trades that generate shifts in the DJIA. The DJIA thus serves as something of a composite index of economic factors of political interest. Second, although the members of the public are probably not aware of much of the information that goes into these trades, many of them will be aware of changes in the DJIA because these are so widely published in newspapers and reported on daily radio and television news broadcasts. Finally, our time-series of presidential approval is composed of weekly aggregations, while most aggregate economic indicators are available only on a monthly or quarterly basis. The DJIA, however, is easily aggregated on a weekly basis and is often reported to the public as weekly changes. Growth was measured as the weekly opening price of the DJIA subtracted from the weekly closing price and divided by the opening price.

35. This measure records only the volume of coverage. It makes no attempt to capture any positive or negative content of the stories. Minutes were aggregated on a weekly basis, and data were drawn from the Tyndall Report. 
forces. Finally, we included dummy variables to mark several important events in the flow of the war in Iraq. In addition to dummy variables for the onset of the combat, occupation, and Iraqi sovereignty periods, we provided a dummy variable for the capture of Saddam Hussein in December 2003, which had a significant-though brief-positive impact on the public's perception of the success of U.S. operations. We also include a dummy variable for the release of the Kay report in January 2004, which indicates that Iraq may not have possessed stockpiles of weapons of mass destruction as the Bush administration had contended. ${ }^{36}$ All independent variables were lagged one week. ${ }^{37}$

Model 1 in Table 1 examines Mueller's hypothesis that public support for a war will erode with the log of military deaths. Contrary to Mueller's finding on the Korea and Vietnam cases, the log of casualties does not fit the Iraqi war data and, in fact, the overall fit of this model is poor. None of the variables associated with the war are statistically significant. The only statistically significant effect is the volume of media coverage of Democratic presidential candidates. The coefficient for the log of casualties is minuscule and does not approach significance, indicating that casualties —on average- had no impact at all on presidential approval from March 2003 through November 2004.

In model 2, however, we allow for the possibility that U.S. military casualties may have had very different effects on presidential approval during the major combat, occupation, and sovereign Iraq phases of the war because of the substantial differences in public expectations of U.S. success. The overall fit of the model is dramatically improved. Whereas model 1 yielded an $R$-squared of 0.53 , making the impact of casualties contingent on the phase of the war increases the $R$-squared to 0.83 . Because of the interaction between casualties and approval in model 2, calculating the overall effect of casualties for each phase of the war-and the proper standard errors for hypothesis testing-is more complex. Thus we calculate the overall impact of casualties on presidential approval for each of the three phases of the Iraq war in Table 2. The shift

36. These dummy variables set a new intercept value for the presidential approval time-series after each event occurs. The dummy variables are coded 0 prior to the occurrence of the event and 1 afterward. Controlling for the initiation of the war as a "rally event" had no impact on the coefficients in Table 1, and the variable was not statistically significant. This is probably because the casualties suffered during the major combat phase capture the rally effect.

37. A Phillips-Perron unit root test indicated that the presidential approval time-series is trend stationary $(p<0.05)$. The coefficients in Table 1 use the Prais-Winsten correction for serial correlation in a time-series. The estimated rho for models 1 and 2 were 0.82 and 0.27 , respectively. The initial Durbin-Watson statistics were 1.18 and 1.61, indicating a statistically significant autocorrelation problem for both models. The transformed Durbin-Watson statistics were 2.35 and 2.03, indicating that the Prais-Winsten correction addressed the problem. 
Success Matters $\mid 21$

Table 1. U.S. Military Casualties and Presidential Approval, January 2003November 2004

\begin{tabular}{|c|c|c|}
\hline Explanatory Variable & $\begin{array}{l}\text { Model 1: } \\
\text { Constant Impact } \\
\text { of Casualties }\end{array}$ & $\begin{array}{l}\text { Model 2: } \\
\text { Contingent Impact } \\
\text { of Casualties }\end{array}$ \\
\hline Log of total casualties & $\begin{array}{c}0.101 \\
(0.12)\end{array}$ & $\begin{array}{l}2.255 \\
(4.21)^{* *}\end{array}$ \\
\hline Casualties x U.S. occupation & & $\begin{array}{c}-11.642 \\
(6.29)^{* *}\end{array}$ \\
\hline Casualties $\mathrm{x}$ Iraq sovereign & & $\begin{array}{c}-2.363 \\
(0.28)\end{array}$ \\
\hline U.S. occupation & $\begin{array}{c}-1.634 \\
(0.60)\end{array}$ & $\begin{array}{l}55.157 \\
(5.41)^{* *}\end{array}$ \\
\hline Iraq sovereign again & $\begin{array}{c}-3.340 \\
(0.78)\end{array}$ & $\begin{array}{c}-3.377 \\
(0.06)\end{array}$ \\
\hline After Saddam Hussein captured & $\begin{array}{c}-2.625 \\
(1.08)\end{array}$ & $\begin{array}{c}3.850 \\
(2.30)^{*}\end{array}$ \\
\hline After release of the Kay report & $\begin{array}{c}-1.047 \\
(0.43)\end{array}$ & $\begin{array}{c}-3.034 \\
(2.03)^{*}\end{array}$ \\
\hline Prewar media coverage of Iraq & $\begin{array}{c}0.042 \\
(1.28)\end{array}$ & $\begin{array}{c}0.061 \\
(2.19)^{*}\end{array}$ \\
\hline Media coverage of major combat & $\begin{array}{c}0.026 \\
(1.93)\end{array}$ & $\begin{array}{c}0.030 \\
(3.49)^{* *}\end{array}$ \\
\hline Media coverage of insurgency & $\begin{array}{c}0.017 \\
(1.58)\end{array}$ & $\begin{array}{c}0.008 \\
(0.80)\end{array}$ \\
\hline Media coverage of sovereign Iraq & $\begin{array}{c}0.021 \\
(0.91)\end{array}$ & $\begin{array}{c}-0.008 \\
(0.37)\end{array}$ \\
\hline Media coverage of Democrats & $\begin{array}{c}-0.032 \\
(2.28)^{*}\end{array}$ & $\begin{array}{c}-0.036 \\
(2.61)^{*}\end{array}$ \\
\hline Growth in Dow Jones Industrials & $\begin{array}{c}9.890 \\
(0.78)\end{array}$ & $\begin{array}{c}26.441 \\
(1.92)\end{array}$ \\
\hline Constant & $\begin{array}{l}55.790 \\
(13.49)^{* *}\end{array}$ & $\begin{array}{l}53.348 \\
(21.25)^{* *}\end{array}$ \\
\hline $\begin{array}{l}\text { Observations } \\
R \text {-squared }\end{array}$ & $\begin{array}{l}96 \\
0.53\end{array}$ & $\begin{array}{l}96 \\
0.83\end{array}$ \\
\hline
\end{tabular}

NOTE: Absolute value of $t$ statistics appears in parentheses.

* significant at 5 percent; ** significant at 1 percent 


$\begin{aligned} & \text { Table 2. The Contingent Impact of Casualties on Presidential Approval during the } \\
& \text { Iraq War, March 2003-November } \mathbf{2 0 0 4}\end{aligned}$
\begin{tabular}{llll} 
Phase of Iraq War & $\begin{array}{l}\text { Coefficient for } \\
\text { Impact of Casualties }\end{array}$ & Standard Error & $\begin{array}{l}\text { Level of Statistical } \\
\text { Significance }\end{array}$ \\
\hline Major combat & 2.26 & 0.536 & $<0.001$ \\
U.S. occupation & -9.34 & 1.77 & $<0.001$ \\
Iraqi sovereignty & -0.108 & 8.48 & $<0.990$ \\
\hline
\end{tabular}

from major combat to the insurgency against the U.S. occupation had a negative effect on the relationship between casualties and presidential approval. Specifically, the coefficient shifts from 2.26 to -9.34 . Both of these effects are statistically significant. Notice, however, that after the United States transferred sovereignty to an Iraqi authority, the impact of casualties shifts again. Consistent with our impressionistic evaluation of Figure 1, the model indicates that, between June and November 2004, casualties had no impact on presidential approval. The coefficient is reduced to -0.108 , and the effect does not approach statistical significance. Such attenuation in the impact of casualties is particularly striking in light of the tremendous media coverage given to the death toll as the number of U.S. troops killed in action approached 1,000.

The shift between the occupation and sovereign Iraq phases of the war indicates that the relationship between casualties and presidential approval is not constant. The data cannot be explained as a brief rally effect followed by a steady decline in approval in response to mounting casualties. This result does not imply that the public did not care about U.S. casualties after the transfer of sovereignty, but it does suggest that its tolerance for casualties increased between June and November 2004.

Accounting for the varying impact of casualties improves the fit of the model so much that it allows us to detect the impact of other variables as well. As Table 1 shows, we can see that the volume of media coverage can have varying influences on presidential approval. For example, media coverage of Iraq evoked a rally effect prior to the outbreak of the war and during the major combat phase; but coverage of combat since the onset of the insurgency has had no impact. Not surprisingly, media coverage of Democratic presidential candidates reduced presidential approval. Other events on the ground in Iraq influenced approval as well. For example, the capture of Saddam Hussein in December 2003 boosted approval by nearly 4 percentage points, while the release of the Kay report shrank approval by 3 points. Moreover, the DJIA does 
have a statistically significant and substantively important impact on presidential approval.

Our data on casualties and presidential approval closely correspond with those of Eichenberg and Richard Stoll, who analyzed similar data with a slightly different statistical model and concluded that with every additional 100 casualties and controlling for the rally effect, approval of the president's handling of Iraq dropped 3 percentage points, and approval of the president overall dropped by about 1 percentage point. ${ }^{38}$ We depart from Eichenberg and Stoll's interpretation by distinguishing between the differing effects of casualties during the major combat, occupation, and sovereign Iraq phases of the war. This pattern of varying levels of public casualty sensitivity also fits the results Feaver and Gelpi found when examining other conflicts, including reanalyzing Mueller's data on public opinion during the Korean and Vietnam Wars. ${ }^{39}$ When the public appears to be confident of a U.S. victory, casualties have little effect on popular support. But if the public's confidence is shaken, then casualties erode support. When this occurs, the relationship appears to be logarithmic. That is, small numbers of casualties will matter early on in a conflict, but as the combat deaths escalate, it takes increasingly large increments of military deaths to reduce support. This relationship, however, is conditional on low expectations of success.

Anecdotal evidence from available polls suggests that these shifts in casualty tolerance relate to the U.S. public's expectations of success. During the major combat phase, the public was confident, and rightly so, that the United States could invade Iraq and remove Saddam Hussein from power. As early as March 27, 2003-prior to the fall of Baghdad in April-a Time/CNN poll reported that 52 percent of the public was already willing to label the war a success. ${ }^{40}$ But the onset of the insurgency against the occupation in May shook the public's confidence in a successful outcome. In mid-July another Time/CNN poll asked the same question and found that only 39 percent of respondents felt that the U.S. effort was a success-even though the United States had toppled Hussein and occupied Iraq. ${ }^{41}$ By November 2003 only 25 percent of the public stated that the war had been successful. ${ }^{42}$ The granting of sovereignty

\footnotetext{
38. Richard C. Eichenberg and Richard J. Stoll, "The Political Fortunes of War: Iraq and the Domestic Standing of President George W. Bush" (London: Foreign Policy Centre, July 2004).

39. Feaver and Gelpi, Choosing Your Battles, pp. 132-144.

40. Time/CNN/Harris poll, March 27, 2003.

41. Time/CNN/Harris poll, July 16, 2003.

42. Time/CNN/Harris poll, November 18, 2003.
} 
and creation of an Iraqi government also seem to have reflected a similarthough less dramatic-shift in public optimism. By May of 2004 public confidence reached its nadir with only 37 percent of respondents stating that the war was going "very well" or "somewhat well." But by the eve of the presidential election in October 2004, that number had risen to 57 percent. $^{43}$

The attitude tapped by these Time/CNN polls, however, differs from the "expectations of success" concept emphasized here. These polls asked respondents to make a judgment about accomplished fact-was the war a success now-rather than a judgment about the likelihood of the future event-will the war eventually be successful? Our thesis is that expectations of future success are the key determinants of public casualty tolerance. That is, the U.S. public can accept that the war is not yet won and will involve continued and even mounting costs, provided that events thus far are not convincing it that eventual success is impossible. But other factors may also have been shifting when the Time/CNN polls were taken. More generally, we cannot base inferences about individual attitudes solely on shifts in aggregate opinion. In fact, one of the principal weaknesses of the current analyses of public opinion and casualty tolerance is the almost exclusive reliance on aggregate data. Thus Mueller, Jentleson, Larson, and often Feaver and Gelpi are left in the difficult position of observing shifts in aggregate support for military operations in published polls and then inferring the cause of fluctuations in support from external events. ${ }^{44}$ Such inferences are made even more problematic by the obvious ecological inference problem involved in reaching such conclusions. To achieve firm conclusions about the process by which individual members of the public form attitudes about tolerating the costs of war, we must collect and analyze data on individuals' opinions.

\section{Sources of Individual Variation in Casualty Tolerance}

Beginning in October 2003 and extending through October 2004, we conducted a series of surveys of public attitudes toward the Bush administration's decisions to use force and toward the current war in Iraq in particular. Our survey tapped respondents' views about the primary policy objective, the extent of

43. CBS News poll, May 23, 2004. October data are from October 15 through November 1, 2004. Our question labels the second category "fairly well" instead of "somewhat well."

44. Mueller, War, Presidents, and Public Opinion; Jentleson, The Pretty Prudent Public; Britton and Jentleson, "Still Pretty Prudent," p. 395; Larson, Casualties and Consensus; and Feaver and Gelpi, Choosing Your Battles. 
elite consensus, and their confidence in victory. Following on work by Jentleson, Larson, and Kull, among others, we suggest that overall the U.S. public follows a prudent and reasonable path in deciding whether it will tolerate U.S. casualties in a military operation. ${ }^{45}$ Our principal difference with Jentleson, Larson, and Kull is not over the prudence of the U.S. public, but over the relative importance of various factors in their calculations.

We argue that survey respondents' tolerance for casualties in the war in Iraq is a function of two central explanatory variables: (1) the extent to which they believe that President Bush did the right thing in attacking Iraq, and (2) the extent to which they believe that the United States will emerge victorious. Those who feel strongly that the president "did the right thing" in attacking are expressing a belief that the Bush administration had good cause for using military force in this case. ${ }^{46}$ Respondents could have many reasons for stating that the president did the right thing by using military force-including the desire to enforce UN resolutions, the desire to keep the United States secure from suspected Iraqi WMD, the desire to prevent Iraq from sharing suspected WMD with terrorists, the desire to promote human rights and punish a vicious dictator, or the desire to instill democratic governance in the Middle East. Whatever policy goals individuals may emphasize in their thinking about why the president did the right thing, we are arguing that it is something for which they would be willing to pay a cost if the goal were achieved.

The second variable captures a respondent's judgment about the likelihood that the United States will be able to achieve whatever goals he or she believes are at stake in Iraq. Our measure attempts to separate beliefs about likely victory from any expectations of benefits. Specifically, we asked respondents: "Regardless of whether you think that the president did the right thing, would you say that the U.S. is very likely to succeed in Iraq, somewhat likely to succeed, not very likely to succeed, or not at all likely to succeed?" We did not specify for respondents what success might mean; as we discuss below, we probed that question in follow-on surveys.

These two attitudes can combine in four basic ways. Respondents in the first category, which in this case might be considered the "Bush base," believe that the war was right and that the United States will win. Those in the opposing

45. Jentleson, "The Pretty Prudent Public"; Larson, Casualties and Consensus; and Larson, "Putting Theory to Work."

46. We asked respondents, "I would like to know whether you think President Bush did the right thing by using military force against Iraq. Would you say that you strongly approve, somewhat approve, somewhat disapprove, or strongly disapprove of his decision?" 
category, which we call "the Vietnam syndrome," believe that the war was wrong and the United States will lose. Obviously, we would expect the former group to have much greater casualty tolerance than the latter group. But respondents with intermediate attitudes-the "noble failure" view that the war was right, but the United States will lose, and the "Pottery Barn we broke it, we'll fix it" view that war was wrong, but the United States will win-pose more interesting theoretical questions that allow us to compare the relative importance of the two attitudes in shaping casualty tolerance.

We contend that expectations of success will matter more, and thus the "Pottery Barn" respondent will express a greater tolerance than the "noble failure" respondent for the human costs of the war. Even if one believes that the United States was unjustified in attacking Iraq, failure could damage its reputation or leave Iraq even more vulnerable to the infiltration of terrorist groups-all would mean that U.S. lives were lost in vain. Indeed, some could argue that once a conflict has begun, the United States has an intrinsic national interest in winning regardless of the original rationale.

To compare our argument about the interactive impact of "rightness" and expected success to other prominent arguments about the sources of casualty tolerance, we also included control variables to capture the effects hypothesized by Jentleson, Larson, and Kull. As we noted above, Jentleson argues that casualty tolerance will be higher when the public believes that the primary policy objective of the mission involves the defense of the United States or its allies against outside attack. With regard to the debate surrounding the war in Iraq, this attitude was most centrally focused on the question of whether the war in Iraq should be considered a part of the Bush administration's "war on terrorism." In the wake of the September 11 attacks, the war on terrorism was widely perceived as addressing a threat to the U.S. homeland. The Bush administration argued that Iraq posed a similar threat, by virtue of the possible nexus between alleged Iraqi pursuit of WMD and alleged Iraqi links to terrorists who might use them. Even the administration's third pillar-namely, the humanitarian argument about ridding the region of Hussein's oppressive rule and thereby creating the conditions for democracy to take hold in the Middle East-had a link to the broader war on terror, because the administration maintained that the spread of democratic freedoms was the most effective long-term solution to addressing the root causes of terrorism. If the survey respondents did not perceive any link between Iraq and the broader war on terror, the case for war rested on a strictly humanitarian argument (or perhaps a legalistic one about enforcing UN resolutions). Thus in Jentleson's terms, the 
central factor determining respondents' casualty sensitivity should be the extent to which they believe that the Iraq war is linked to the war on terrorism. ${ }^{47}$

Larson's model of the public's cost-benefit evaluation of war includes a wide range of variables, but he gives pride of place to public perceptions of an elite consensus in support of the mission. According to this view, the public takes cues from the political elite in deciding whether to support a military operation. To the extent that elites from across the political spectrum support an operation, members of the public will also be supportive. Measuring the extent of elite consensus presents difficult problems, complicating analyses of the aggregate relationship between consensus and public support. Because we are analyzing individual-level attitudes, however, the key variable for Larson should be the extent to which a respondent perceives an elite consensus in support of the war. Thus we asked respondents whether they believed that Republican and Democratic leaders agree that the United States should remain in Iraq until the Iraqi government is stable and secure. ${ }^{48}$

Finally, Kull's recent work has emphasized public attitudes toward multilateralism as critical in determining public tolerance of casualties. Numerous polls indicate that the American public looks favorably on gaining allied support for U.S. military operations and on obtaining UN Security Council authority for using force. This minimal level of multilateralism, however, does not adequately measure the impact that multilateralism should have on casualty tolerance and the war in Iraq. After all, even many policymakers who are widely viewed as unilateralist would agree that ceteris paribus it is better to have multilateral international support. The critical question is: What should the United States do if it is unable to obtain international legitimization for a particular mission? With regard to UN authorization, for example, should the president proceed with a mission alone if he deems it necessary and cannot persuade the United Nations to sanction force? Or should he postpone the mission until he is able to obtain support from the Security Council? To the extent that multilateralism has a substantive constraining effect on U.S. policy, we contend that it implies the latter attitude. Thus Kull's argument about the

47. We asked the question, "Which of the following best describes your beliefs about the war in Iraq and the war on terrorism?" Respondents were given four possible response categories: (1) Iraq is the "central front" in the war on terror; (2) the war in Iraq is "an important part of the war on terrorism, but it is not the central battle"; (3) Iraq is "not a part of the war on terrorism"; and (4) the war in Iraq is "a distraction from the war on terrorism."

48. The question was posed as follows: "Do you think America's political leaders-both Republican and Democrat-agree that the U.S. troops should remain in Iraq until the new Iraqi government is stable and secure?" Respondents could answer yes or no. 
impact of multilateralism on public support implies that respondents who hold the latter belief should be substantially less willing to tolerate casualties in Iraq, because the president chose to launch the attack without explicit UN approval. $^{49}$

\section{MEASURING CASUALTY TOLERANCE}

Our dependent variable is the survey respondents' willingness to continue to support military operations in Iraq as the human cost continues to mount. Specifically, we asked: "Regardless of whether you think the president made the right decision in attacking Iraq, as you know the United States is engaged in an ongoing military operation there and has suffered about military deaths in combat. ${ }^{50}$ Would you support continued U.S. military action in Iraq until a new Iraqi government can take over if it resulted in no additional U.S. military deaths?" If a respondent answered affirmatively, we asked the question again, this time raising the number of deaths. Those who answered negatively moved on to the next question. In the October 2003 survey, respondents had a chance to answer if they would support the war if there were up to 500 deaths, then to 5,000, and finally to 50,000, jumping to the next level if the respondent stated that he or she would continue to support the operation. The lowest casualty threshold-500 deaths-was updated in subsequent surveys as the number of U.S. combat deaths increased. ${ }^{51}$ We continued to ask about tolerance for about 200-400 or more than the number the United States suffered at the time of the survey. Since the rate of U.S. military deaths has remained consistent since the end of major combat operations, our question essentially asked respondents if they were willing to continue supporting the war in Iraq for at least the next three to six months. ${ }^{52}$

49. We asked, "Before deciding to take military action, the president often seeks the approval of international organizations like the United Nations. What should the president do if he is not able to gain that approval? The response options were (1) "he should not take military action period, regardless of whether he can get international approval"; (2) "he should delay military action until he receives international approval"; (3) "he should take military action even without international approval if he thinks it is necessary"; and (4) "he should not seek international approval before deciding to take military action."

50. We inserted the appropriate death toll at the beginning of each wave.

51. Any potential bias from changes in question wording would tend to exaggerate the apparent casualty sensitivity in the new surveys. As we are arguing that the public is more casualty tolerant than commonly believed, this poses no problems for our analysis.

52. We believe that this measure of casualty tolerance can better gauge the policy-relevant issue of continued support of an ongoing military operation than other more commonly used measures of casualty sensitivity. For example, analysts often evaluate responses to questions about whether the war in Iraq has been "worth it" as measures of casualty tolerance. But after asking whether the 
This series of questions produced a five-category ordinal variable. The first category represents those who said they would not support the war even if there were no more U.S. military deaths; one might think of this as a "stop now" sort of response. The second category represents those who stated that they would support the war if no more U.S. soldiers were killed, but would not support the war if there were a total of 500 U.S. military deaths. We label these respondents as "casualty phobic" because they are willing to support the operation, but only if the human costs are minimally higher than they were at that point (around 300 combat deaths). As noted above, the third category of respondents essentially offers policymakers a window of opportunity to prosecute the war. They stated they would support the war despite an additional 200 to 300 deaths, but would not support the war if 5,000 U.S. soldiers were killed. The remaining categories of respondents were varying levels of "Iraq hawks," promising continued support of the war even if casualties mounted to levels far in excess of anything military experts expected given the situation in October 2003. The fourth category promised continued support if 5,000 U.S. soldiers were killed but would withdraw support if the United States suffered 50,000 military deaths. The fifth category of respondents stated that they would support the war even if the United States suffered 50,000 deaths.

We followed up the October 2003 poll with a series of short polls from February through June 2004, asking a similar casualty question updated to reflect the new casualty tally. In surveys from February through April, we set the window of opportunity threshold for casualty tolerance at 1,000 U.S. military deaths. In June 2004, we increased the window of opportunity to 1,500 because of the rising U.S. death toll. Finally, in the last two weeks of October

\footnotetext{
Iraq war has been "worth it," we probed respondents about why the war was or was not "worth it." Approximately 45 percent of respondents who felt that the Iraq war was not "worth it" indicated that they felt this way because "the U.S. should not have gone to war over this issue in the first place." Fewer than one-third of those who responded that the war was not "worth it" stated that the most important reason for their response was the number of U.S. soldiers killed. Moreover, in October 2004 more than 25 percent of the respondents who stated that the Iraq war had not been "worth it" still stated that they would support the war if there were as many as 1,500 U.S. combat deaths. Thus "worth it" questions appear to tap some mixture of respondents' views about casualty tolerance, their evaluation of the reasons for fighting, and their assessment of the prospects of success, making those data less useful for examining relationships among those various attitudes. Our measure more effectively isolates attitudes about the willingness to bear the costs in lives lost and frames the question in a way most relevant to policymakers: Will the respondent be willing to continue to support an ongoing military operation in the face of rising costs? This distinction may explain why public opposition to the war-measured in terms of electoral consequences for the president or the extent of public demonstration and outcry-has not grown as swiftly as the number of respondents saying the war has not been "worth it."
} 
2004, we conducted a larger survey in the context of the November presidential election. In this survey, the window of opportunity was also set at 1,500. For this larger survey, we also gathered data on respondents' attitudes toward the primary policy objective of the Iraq war, perceived elite consensus, and their views on the importance of multilateralism in the U.S. decision to use force.

Table 3 presents the summary statistics for the questions used to construct our ordinal dependent variable. These are separate samples, not panel data, limiting our ability to draw inferences about changes over time. The results suggest four important points, however. First, our survey question appears to be tapping into real attitudes because the numbers are stable yet move in sensible ways; as the casualty toll mounts, the proportions in the various groups shift accordingly, except for the "Iraq hawks" whose professed casualty tolerance vastly exceeds the actual mounting death toll.

Second, like most questions about tolerance for casualties, the questions in our surveys tend to exaggerate public casualty sensitivity. ${ }^{53}$ Although rising casualties did shift the aggregate response to our casualty tolerance question, they did not do so by as much as the earlier survey responses suggested they would.$^{54}$ Moreover, the response options capture only crude jumps. A respondent who might tolerate up to 2,000 or even 4,000 casualties but not 5,000 is coded as accepting "at least 1,000 casualties" in our data.

Third, even with this biased estimator, the public shows more casualty tolerance than the conventional wisdom suggests. Finally, consistent with our expectations from the aggregate data analysis, our data indicate that public casualty tolerance actually rose between June and October 2004. This increase occurred despite the massive media coverage given to passing the threshold of 1,000 U.S. combat deaths in Iraq. Specifically, in October, 50 percent of the respondents stated that they would be willing to tolerate 1,500 U.S. military deaths, whereas only 44 percent expressed that view in June.

These summary results tell an important and interesting story, but the data are even more valuable as a tool for tapping into the microfoundations of public attitudes on casualties: How does the public form its attitudes on casualties, and which factors are the most important?

53. For an account of question wording effects and the use of hypothetical scenarios to measure casualty tolerance, see Feaver and Gelpi, Choosing Your Battles.

54. One possible explanation for this phenomenon is sunk-costs thinking on the part of the respondents. That is, as the United States pays higher costs in Iraq, the public may become more determined to ensure that those losses are not in vain. 
Success Matters 31

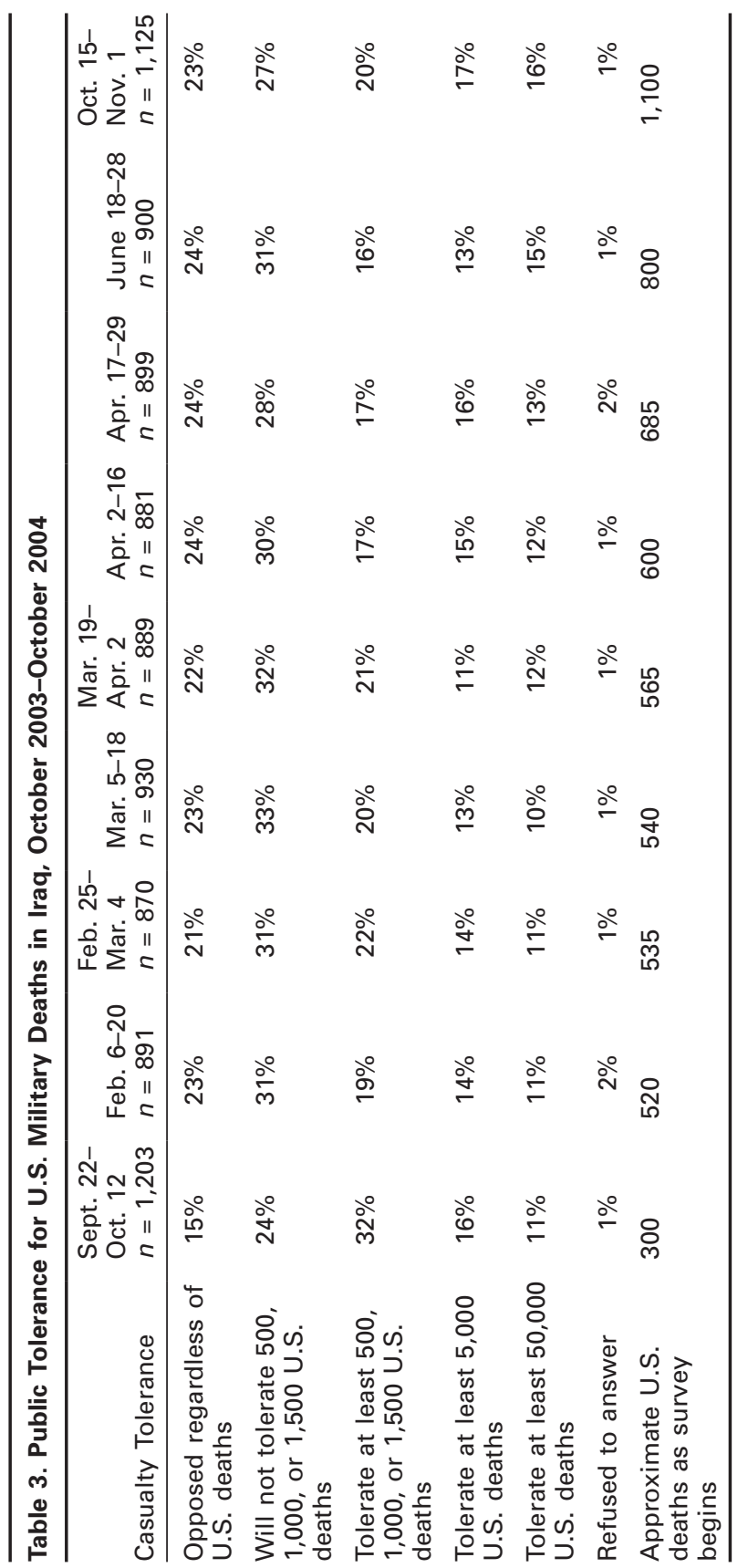


ANALYZING INDIVIDUAL ATTITUDES TOWARD CASUALTY TOLERANCE

The results of our individual-level analysis of public tolerance for casualties in Iraq in October 2004 are displayed in Table 4. We use ordered logit, which is analogous to linear regression, but is the most appropriate statistical method for analyzing an ordinally ranked dependent variable when the thresholds between categories are not evenly spaced. The results provide strong support for each of our expectations regarding the nature of the U.S. public's tolerance for casualties. Interpretation of the specific coefficients requires some care because of the interaction between perceived rightness or wrongness of the war and expected success and tolerance for costs, but a careful review of the coefficients indicates that our interactive model of the "rightness" of the war and expectations of success has a significant impact on tolerance for casualties. ${ }^{55}$

The coefficient for respondents' attitudes about whether President Bush did the right thing represents the impact of respondents' views regarding the rightness of the war on their tolerance for casualties when respondents believe that the United States is not very likely to succeed. Similarly, the coefficient for respondents' attitudes about whether the United States is likely to succeed in Iraq represents the impact that expectations of success have on respondents' tolerance for casualties when they strongly disapprove of the president's decision to go to war. As expected, the coefficient for expectations of success is larger than the coefficient for the justification of the war. A chi-squared test reveals that this difference is statistically significant (chi $=13.04,1$ d.f., $p<0.001$ ). This result indicates that expectations about victory have a greater impact on casualty tolerance when respondents are skeptical about the justification of the war than their views about the rightness of the war have when they are skeptical about victory.

Respondents who are skeptical of the rightness of the war yet expect the United States to win may be willing to pay higher costs than those who believe in the cause yet expect to lose, but the results in Table 4 also clearly indicate that these attitudes interact in determining an individual's tolerance for casu-

55. There is no simple "goodness of fit" measure for ordinal logit models. Pseudo $r$-squared measures vary widely and other intuitive measures such as the percentage of correct predictions are also arbitrary. See Scott Demarchi, Christopher Gelpi, and Jeffrey Grynaviski, "Untangling Neural Nets," American Political Science Review, Vol. 98, No. 2 (June 2004), pp. 371-378. The best available measure of fit for dichotomous logit or probit models is the Receiver Operating Characteristic (ROC) curve, but this measure is not appropriate for polytomous dependent variables. If one uses the model in Table 3 to make dichotomous predictions about whether respondents will fall in the "window of opportunity" category (i.e., tolerate at least 1,500 U.S. deaths), the area under the ROC curve in this model is a respectable 0.78 (95 percent confidence interval 0.76 to 0.81 ). 
Table 4. The Individual Sources of Public Tolerance for Casualties in Iraq, October 2004

\begin{tabular}{lc}
\hline Explanatory Variable & Coefficient \\
\hline Bush did the right thing & 0.038 \\
United States will succeed & $(0.27)$ \\
& 0.582 \\
Right thing X will succeed & $(4.18)^{* *}$ \\
Perceived elite consensus & 0.241 \\
& $(3.64)^{* *}$ \\
Oppose force without UN approval & 0.645 \\
& $(5.19)^{* *}$ \\
Terrorism is primary policy objective in Iraq war & -0.333 \\
& $(3.45)^{* *}$ \\
Female respondent & 0.158 \\
& $(1.99)^{*}$ \\
Nonwhite respondent & -0.242 \\
& $(2.01)^{*}$ \\
Age & -0.666 \\
Education level & $(3.91)^{* *}$ \\
Party identification & 0.122 \\
Observations & $(2.07)^{*}$ \\
\end{tabular}

NOTE: Absolute value of $t$ statistics appear in parentheses.

* significant at 5 percent; ${ }^{* *}$ significant at 1 percent

alties. The coefficient for the interaction term, "Right Thing x Success," is positive and statistically significant, indicating that each of our key variablesviews of the rightness of the war, and expectations of success-has a greater impact on casualty tolerance as the other variable increases. That is, one's expectations regarding success have a greater impact on casualty tolerance if one believes that President Bush was right to attack Iraq than if one believes that he was wrong to do so. Similarly, one's views regarding the rightness of the war have a greater impact on casualty tolerance if one expects the United States to win the war than if one is skeptical of success.

Although our argument concerning the sources of casualty tolerance receives strong statistical support, so do the arguments made by Jentleson, Larson, and Kull. Each of the control variables measuring perceptions of the links between Iraq and the war on terror, perceptions of an elite consensus, and support for international constraints on the U.S. use of force are statistically significant in the expected direction. Specifically, both the belief that Iraq 
is a part of the war on terror and the belief that Democratic and Republican leaders all support a continued U.S. presence in Iraq significantly increase a survey respondent's casualty tolerance. On the other hand, the multilateralist belief that the United States should delay using force until it obtains UN approval reduces casualty tolerance in this case.

Thus we find statistical support for all four central arguments about the sources of casualty tolerance. But how important are these attitudes relative to one another? The substantive effects of the rightness of the war and expectations of success are displayed in Figure 2. The vertical axis represents the probability that a respondent would tolerate at least 1,500 casualties.

The axis running from left to right depicts changes in a respondent's attitude about the likelihood that the United States will succeed in Iraq, while the axis running from the front of the figure to the back depicts changes in a respondent's attitude toward whether President Bush did the right thing in choosing to use force against Iraq. The columns depicting predicted casualty tolerance demonstrate the interactive nature of the relationship between these variables. Not surprisingly, casualty tolerance is at its lowest point in the left-front "Vietnam syndrome" corner of Figure 2 when a respondent strongly disapproves of the decision to attack and thinks the United States is not at all likely to succeed. Casualty tolerance is at its highest in the right-rear "Bush base" corner when a respondent strongly approves of the decision to attack and thinks the United States is very likely to succeed. But what the figure also demonstrates is that the impact of each of these variables on an individual's willingness to bear costs and support the war varies dramatically. For example, in examining each row of columns moving from front to back, one can see the impact that changes in a respondent's attitude toward the rightness of the war has on his or her tolerance for casualties at each level different level of expectations regarding U.S. success. Similarly, if one examines each row of columns moving from left to right, one can see that the impact of expectations of success depends on the respondent's level of approval for the initial attack.

Turning to the far left-hand column, one can see that there is virtually no change in a respondent's casualty tolerance as we move from the front to the back of the figure. This row captures the effect of changes in a respondent's attitude toward the rightness of the war when he or she believes that victory is "not at all likely." Under these circumstances, changes in one's attitude about whether President Bush "did the right thing" in attacking Iraq has no impact on tolerance for casualties. Specifically, increasing a respondent's support for the justification of the attack from "strongly disapprove" to "strongly ap- 
\begin{tabular}{l|l} 
Success Matters & 35
\end{tabular}

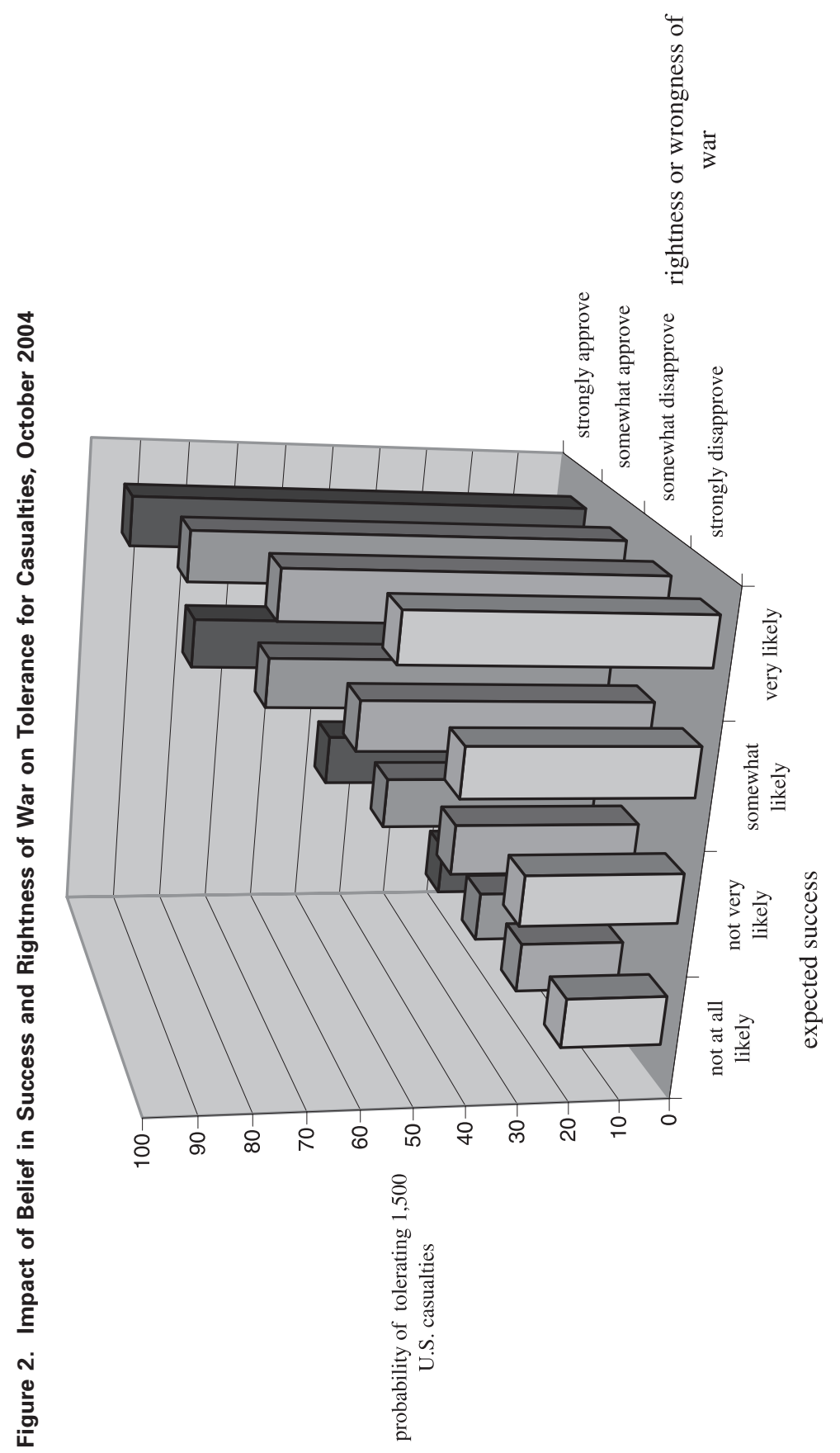


prove" only increases the probability that a respondent will provide the Bush administration with a window of opportunity to prosecute the war from 20 percent to 23 percent.

Moving to the far right-hand row, one can see that the impact of respondent's attitudes toward the rightness of the war becomes much more important if the respondent is optimistic about the prospects for success. Our model predicts a 50 percent chance that a respondent who "strongly disapproves" of President Bush's decision but still believes that the United States is "very likely" to succeed will tolerate at least 1,500 casualties. In this case, however, increasing the respondent's view of Bush's justification for the war to "strongly approve" strengthens the likelihood that he or she would tolerate at least 1,500 casualties to more than 90 percent.

The same type of interactive relationship holds for the impact of expectations of success, but the relationship is stronger in this case. As the front row of columns indicates, for a respondent who "strongly disapproves" of the decision to use force, increasing his or her optimism from "not at all likely" to succeed to "very likely" to succeed increases the probability that he or she will tolerate at least 1,500 casualties from 20 percent to 50 percent. But if a respondent already "strongly approves" of President Bush's decision to attack, then increasing his or her level of optimism from "not at all likely" to succeed to "very likely" to succeed increases the probability that he or she will support a window of opportunity from 23 percent to more than 90 percent.

So which attitude is more important: attitudes toward the rightness of the attack, or those toward the likelihood of success? Both attitudes work together in determining a respondent's threshold for the tolerable human costs of war. The results, however, indicate that - at the margin-attitudes toward expectations of success are more influential than attitudes toward the rightness or wrongness of the conflict. The greater influence of expectations of success can be seen in several places in Figure 2. First, it is illustrated through a comparison of the right-front and left-rear corners of the figure. By comparing the leftrear and right-front columns, one can see that the "Pottery Barn" respondentskeptical of the justification, but optimistic regarding success-has a 50 percent chance of tolerating 1,500 casualties, whereas the "noble failure" respondent has only a 23 percent chance.

One can also see the greater impact of expectations for success by examining some of the intermediate columns. For example, our model predicts that no matter what their views on the justification of the war, a majority of survey respondents will not tolerate at least 500/1,000 casualties if they believe that vic- 
Table 5. Additional Sources of Casualty Tolerance in Iraq, October 2004

\begin{tabular}{|c|c|c|}
\hline Explanatory Variable & $\begin{array}{l}\text { Change in Explanatory } \\
\text { Variable }\end{array}$ & $\begin{array}{l}\text { Change in Probability of } \\
\text { Tolerating At Least 1,500 } \\
\text { U.S. Military Deaths }\end{array}$ \\
\hline Perceived elite consensus & No to yes & $+14 \%$ \\
\hline Oppose force without UN approval & No to yes & $-6 \%$ \\
\hline Terror is PPO of Iraq war & $\begin{array}{l}\text { "Distraction" to } \\
\text { "central front" }\end{array}$ & $+10 \%$ \\
\hline Gender & Male to female & $-5 \%$ \\
\hline Race & White to nonwhite & $-16 \%$ \\
\hline Age & $18-29$ to $60+$ years old & $+8 \%$ \\
\hline Education level & $\begin{array}{l}\text { No high school to } \\
\text { college degree }\end{array}$ & $+18 \%$ \\
\hline Party identification & $\begin{array}{l}\text { Strong Republican to } \\
\text { strong Democrat }\end{array}$ & $-11 \%$ \\
\hline
\end{tabular}

tory is "not very likely" or "not at all likely." Even among those who "strongly approve" of the decision to attack, slightly less than 50 percent of such respondents will tolerate 1,500 casualties if they think that victory is "not very likely." Expectations of success, however, have a considerably greater impact. Our model predicts that 75 percent of respondents who "somewhat disapprove" of President Bush's decision to attack will nonetheless tolerate at least 1,500 U.S. military deaths if they believe that victory is very likely. This implies that the president can garner the support from a majority of those who are moderately skeptical of the war's justification by persuading them that victory is very likely.

Of course, these two attitudes are not the only factors determining a respondent's willingness to tolerate costs in war. As we noted above, we also find support for arguments made by Jentleson, Larson, and Kull. Substantive effects of these variables and the demographic controls are displayed in Table 5. With regard to Jentleson's contention that the principal policy objective is the key to public support, we find that those who believe that the war in Iraq is the "central front" in the war on terrorism are 10 percent more likely to tolerate 1,500 casualties than those who believe that Iraq is a distraction from the war on terror. The perception of an elite consensus supporting U.S. troops in Iraq also increases the likelihood that a respondent will tolerate 1,500 combat deaths by 14 percent. Finally, consistent with Kull's emphasis on multilateral- 
ism, we find that respondents who believe that the U.S. president should refrain from using force until he obtains UN support were 6 percent less likely to tolerate 1,500 U.S. military deaths.

Although the variables identified by Jentleson, Larson, and Kull all influence the public's tolerance for casualties, their substantive impact does not approach the influence of the interaction of the rightness of the war and expectations of success depicted in Figure 1. Whereas other factors may bump the proportion of respondents who are in the window of opportunity up or down by 10 percent to 20 percent, the interaction of rightness and success can have as much as a 70 percent shift up or down in the proportion of respondents in the window. Once we account for this interaction, other factors recede in relative importance.

These results do not necessarily imply, however, that the overall impact of the PPO, perceived elite consensus, and multilateralism are minimal. The effects displayed in Table 5 are estimated on the assumption that attitudes toward the rightness of the war and expectations of success remain constant. Thus our results could indicate that variables such as PPO, perceived elite consensus, and multilateralism influence casualty tolerance indirectly through their impact on attitudes toward the rightness of the war and its prospects for success. ${ }^{56}$

A number of demographic factors also had a significant impact on the public's tolerance for casualties. ${ }^{57}$ With one exception, these effects were in the direction one would expect from intuition and previous research, but none of these effects approach the substantive importance of a respondent's expected value calculation regarding the tolerable cost of the war.

First, somewhat surprisingly, respondents older than fifty-nine are about 13 percent more likely to tolerate at least 1,500 casualties than respondents younger than thirty. ${ }^{58}$ This effect is robust across our nine waves of surveys, but it differs from previous findings on the impact of age. ${ }^{59}$ Second, we find that women are about 6 percent less likely than men to support a window of op-

56. For an examination of this issue, see Gelpi, Feaver, and Reifler, "Paying the Human Costs of War."

57. Feaver and Gelpi, Choosing Your Battles.

58. Our measure divides respondents into four age categories: 18-29, 30-44, 45-59, and over 59.

59. Feaver and Gelpi, Choosing Your Battles. We can only speculate about what may have caused a change in the impact of age on casualty tolerance. One thought is that the possibility of reinstating the draft arose as an issue in the 2004 presidential campaign. Although both candidates rejected the need for a draft, many young voters appeared fearful regarding the possibility. 
portunity for continuing the war. ${ }^{60}$ Third, we find that minorities are about 15 percent less likely than white respondents to tolerate at least 1,500 casualties. It is worth noting, however, that while demographic patterns regarding casualty tolerance such as the gender gap are consistent across a variety of conflicts, minority respondents appear to be less supportive of some wars and more supportive of others. ${ }^{61}$ Education also has a significant impact on the public's tolerance for casualties in Iraq; a college-educated respondent is about 20 percent more likely than a respondent who has not completed high school to tolerate at least 1,500 casualties in Iraq. ${ }^{62}$ Finally, and perhaps not surprisingly, party identification has a significant impact on casualty tolerance-especially in the midst of an election year. Debates over the war in Iraq have often been depicted as highly - if not predominantly-partisan contests. If one makes a simple comparison of partisanship and casualty tolerance, one finds very strong effects. For example, our data indicate that more than 83 percent of our respondents who identify as Republican or leaning Republican stated that they would be willing to tolerate at least 1,500 casualties in October $2004 .{ }^{63}$ But less than 35 percent of those who identified as Democratic or leaning Democratic stated that they would be willing to tolerate that many casualties.

Describing such partisan differences, however, is not the same as explaining them. Much of the reason for the deep partisan divide over the war in Iraq is not because of party loyalty per se. Instead, these differences in tolerance for war costs are largely a result of differing estimations among Democrats and Republicans about the underlying questions about the rightness or wrongness of the war and expectations of success. Once we account for respondents' views regarding the rightness of the war and their expectations for success, partisanship has only a modest impact on casualty tolerance. A respondent who identified him or herself as "strongly Democratic" is only about 10 percent less likely to tolerate at least 1,500 U.S. casualties than if he or she had identified as "strongly Republican"-holding constant the respondent's views on the rightness and likely success of the war. ${ }^{64}$

60. Ibid.

61. Ibid.

62. Education level is coded into four categories: less than a high school diploma, completed high school, some college, and bachelor's or higher degree.

63. We code party identification as a seven-category variable with the following labels: strong Republican, not strong Republican, leans Republican, undecided/independent, leans Democrat, not strong Democrat, strong Democrat.

64. This result suggests that support for the war and for President Bush may be related, but dis- 
Of course, like the PPO, perceived elite consensus, and multilateralism, partisanship may be a key factor in determining those underlying values. Partisanship is especially important in shaping respondent's attitudes regarding whether President Bush did the right thing in choosing to attack Iraq. Nearly 60 percent of our respondents who identified as "Republican" or "leaning Republican" stated that they "strongly approved" of the president's decision to attack. Slightly more than 90 percent stated that they either "strongly" or "somewhat approved." Only about 40 percent of Democrats "strongly" or "somewhat approved." The pattern is similar, but not as strong, with regard to expectations of success.

Finally, the results in Table 4 describe the structure of public attitudes toward casualties in October 2004. But how robust is this structure? To ensure that the process we are observing is robust over time, we performed a similar analysis across the other eight waves of surveys from October 2003. Unfortunately, we were unable to collect data on the control variables for the Jentleson, Larson, and Kull arguments, but we can demonstrate the robustness of the causal process we hypothesize. Analyses of the other survey waves are displayed in an appendix. The coefficients for all the key variables of interest remain very stable across this period, indicating that our results are indeed robust.

\section{How Does the U.S. Public Define and Measure Success in Iraq?}

Across a number of surveys, using a variety of methods on both aggregate and individual-level data, the same consistent conclusion emerges: public expectations of success are central in determining public support for paying the human costs of war. This helps to explain why U.S. public support for the war in Iraq remained fairly robust, despite an unexpectedly bloody and long counterinsurgency, and despite serious doubts being raised about several of the chief justifications for the war: to wit, Americans remained fairly optimistic about the prospects for success in Iraq. But the central role of "expectations of success" begs the obvious next question: How does the public define and measure success in Iraq? Perhaps the public measures success in terms of body bags, in

tinct, attitudes. See Christopher Gelpi, Jason Reifler, and Peter Feaver, "Iraq the Vote: Retrospective and Prospective Foreign Policy Judgments, Candidate Choice, and Casualty Tolerance," Duke University, 2005. 
which case our argument is circular and the conventional wisdom is largely correct.

To address this issue, beginning in February 2004, we followed up our expectations of success question with several additional questions probing the meaning and measurement of success. We asked respondents what success meant to them, based on a range of possible answers that were prominent in public discussions. Table 6 presents the results to this question.

Several remarkable patterns emerge. First, the responses to the question of the definition of success are very stable, astonishingly so when one considers that these responses come from seven different national samples polled over five turbulent months. A "stable and democratic government" was always the first choice, followed closely by "Iraqis provide for their own security" and "Iraqis able to live peaceful, normal everyday lives." Second, the findings strongly suggest that the U.S. public moved on from the WMD and terrorism arguments even as events on the ground moved past those casus belli as well. The public did not treat the apparent absence of WMD stockpiles as a sign that it was time to declare victory and go home. On the contrary, the public moved on to define success in prospective terms that had relevance to the Iraqi situation as it stood in the winter and spring of 2004. Third, the findings suggest that the public may have taken its cues on defining success from the Bush administration, which was itself shifting its rhetorical emphasis from the WMD argument to the importance of establishing a stable democracy in the Middle East. ${ }^{65}$

We also asked respondents how they believed one could best judge whether the United States is on a path toward success. That is, we asked respondents what measures they use to track and estimate future success, again directing respondents to choose from a list of plausible factors. Table 7 presents the results to these questions.

As with definitions of success, the results on tracking success were remarkably stable over the seven polling waves, with one important exception. Although the relative rankings never changed, the primary indicator, "whether Iraqis are cooperating with U.S. authorities and not protecting terrorists and insurgents," increased markedly in prominence as time progressed. This shift is especially noteworthy because it may help to explain both the erosion of

65. Dana Milbank and Mike Allen, "U.S. Shifts Rhetoric on Its Goals in Iraq," Washington Post, August 1, 2003. 
International Security 30:3 42

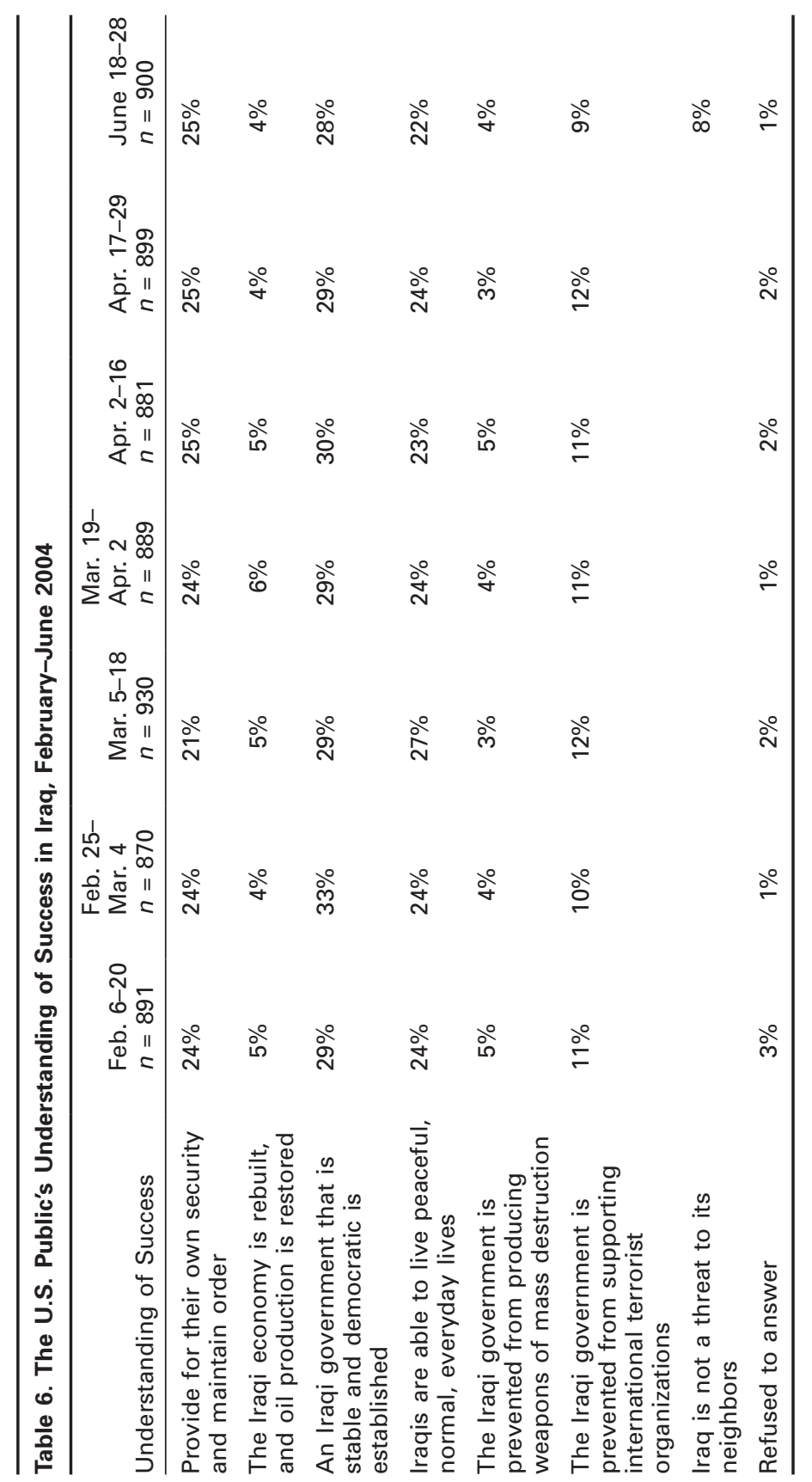




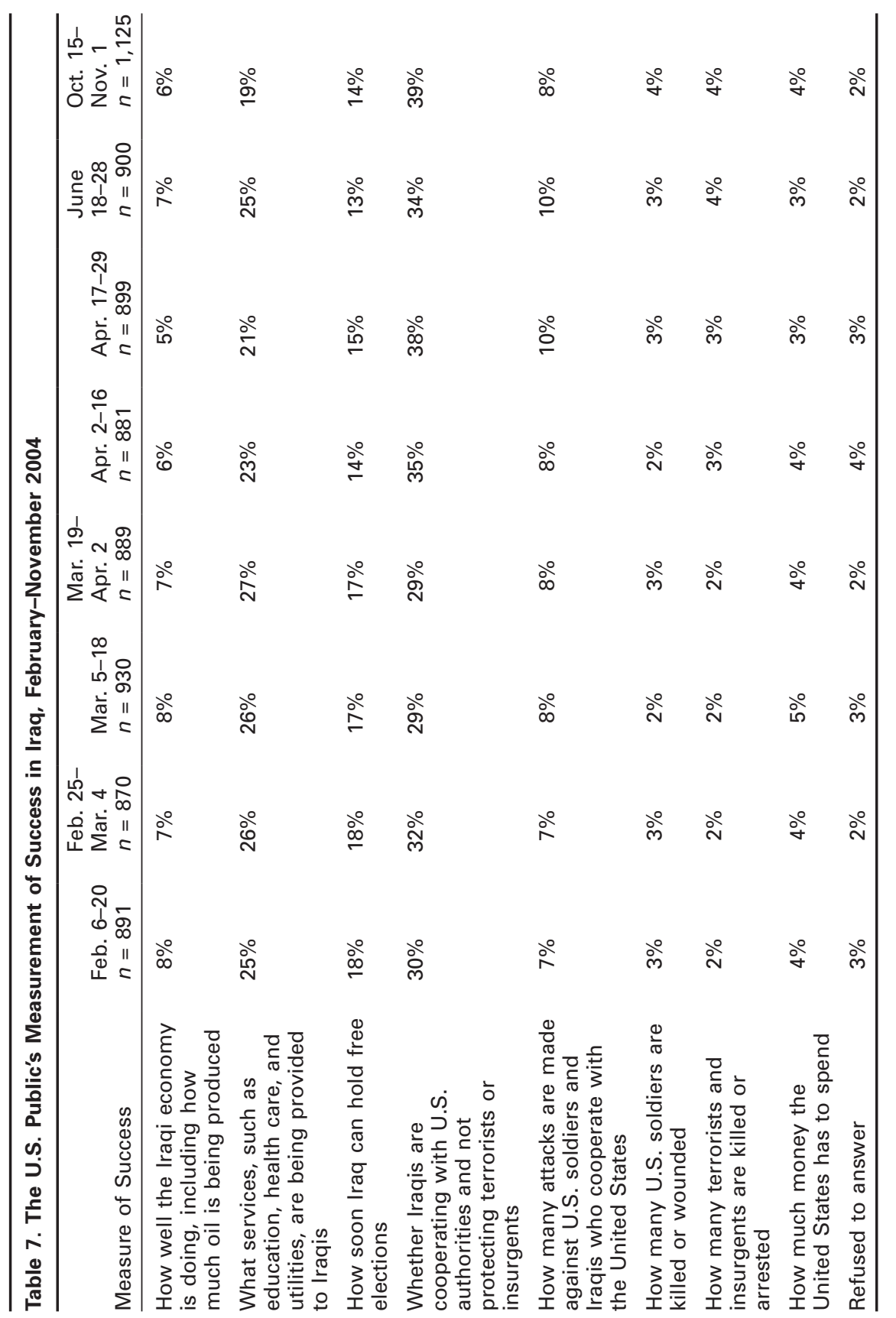


confidence in the spring of 2004 and its stabilization during the summer and fall. The Fallujah and Sadr uprisings that began in mid-March 2004 were dramatic signs that the coalition had not won Sunni hearts and minds, and that it might be in danger of losing a key Shiite constituency as well. Moreover, this ominous view was compounded by reports that the Iraqi security forces trained by the coalition to take over the policing function failed spectacularly in that job. ${ }^{66}$ But the transfer of sovereignty to Iraq and the creation of an Iraqi government appear to have stemmed this tide-at least for a time.

Most important, these results show that our model of casualty tolerance does not rest on a circular argument. The American public does not measure success in terms of whether U.S. soldiers are being killed or wounded nor whether the terrorists and insurgents are being killed or wounded. The measures adopted by the public are rather different, and indeed come closer to the winning-the-hearts-and-minds idea that most experts (and Bush administration rhetoric) would identify as the critical factor. ${ }^{67}$

\section{Conclusion}

The political campaign season of 2003-04 provides an unusually good opportunity to examine the American public's tolerance for paying the human costs of war. Our findings challenge the conventional wisdom on public opinion and U.S. foreign policy, but corroborate much of what other academic studies have found. As John Mueller would expect, public opinion does "harden" to the costs of war as the conflict drags on. Contrary to Mueller's expectations, however, public support for President Bush has not declined inexorably with U.S. casualties. Instead, our analysis shows that the impact of casualties on public approval for the president has varied dramatically between the "major combat," "occupation," and "sovereign Iraq" phases of the war.

What can explain this variation in public tolerance for casualties? Consistent with much of the recent work on public opinion in wartime, our study finds that members of the public appear to be engaging in simple but clear calculations about the expected value of continuing to engage in armed conflict. That is, individuals make judgments about the potential benefits of the conflict and weight those potential gains by the probability that their government will be able to achieve them.

66. Richard Sisk, “Iraqis Now Fight Alongside U.S.," New York Daily News, May 15, 2004.

67. Public attitudes and elite rhetoric are clearly correlated in this case, but we cannot determine the direction of causal influence. 
More specifically, our findings suggest that believing the war was the right thing to do combines with expectations of success to determine an individual's tolerance for the human costs of war. Once one takes into account the interaction of these two attitudes, other prominent variables in the literature have only a modest direct impact on casualty tolerance. This interaction effect even outweighs the independent impact of partisanship. Rather than implying that those other factors are not important, however, it seems likely that many of the variables identified in the literature-such as the partisan cues, primary policy objective, elite consensus, and multilateral support-may be most important through their impact on respondent's views about the rightness of the war and the prospects for success.

Although both the "rightness" of the war and expectations of success are important, our data and analyses indicate that success appears to be the more important factor in this relationship. ${ }^{68}$ Not only do expectations of success have a larger marginal impact on casualty tolerance, but the public also has remained optimistic about success even though it has been divided regarding the justification for the war.

Furthermore, the public does not measure success in terms of body bags. On the contrary, the public claimed to focus on whether the coalition was in fact winning over the hearts and minds of the Iraqi people, as measured by Iraqi willingness to cooperate with coalition forces. The high correspondence between public responses and the Bush administration's rhetoric in this area suggests that leadership may be a key component.

U.S. troops remain engaged in fighting in Iraq and continue to take casualties. The Bush administration remains adamant that it will not cut and run in Iraq, but it is facing increasing domestic pressure at home to do just that. The debate at the elite and public levels is getting more caustic, and on a number of questions the public has turned more negative on the war. But the key tradeoff for the administration is the public's willingness to keep fighting versus the public's demand to pull out of Iraq regardless of the consequences. This balance still seems to tilt in favor of the war. Our model says it will continue to tilt that way so long as the public believes that the United States will achieve victory. If the public ever loses that underlying optimism, then the administration will find continuation of the war politically untenable.

68. The expectation of success is the most important source of casualty tolerance, but our analyses, presented elsewhere, find that beliefs about the rightness or wrongness of the conflict matters more for other factors such as presidential vote choice. See Gelpi, Reifler, and Feaver, "Iraq the Vote," http://www.duke.edu/ gelpi/IraqtheVote.pdf. 
International Security 30:3 46

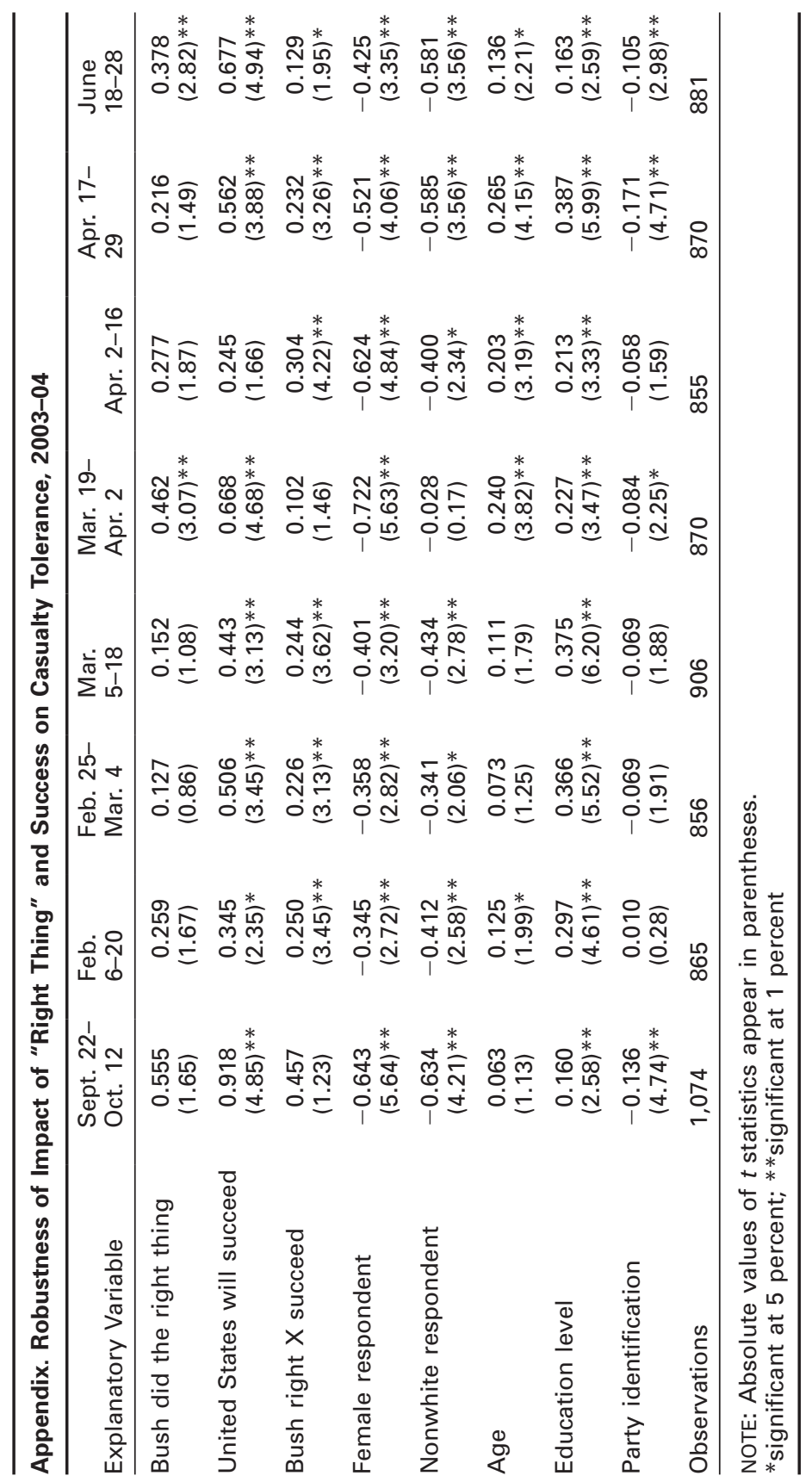

